\title{
Regional Binning for Continued Storage Of Spent Nuclear Fuel and High-Level Wastes
}

October 1998

Prepared for Jason Technologies

6655 West Sahara Avenue

Las Vegas, NV 89102

Report Prepared for Use in Preparation of the Yucca Mountain

Environmental Impact Statement

Report by: W. Lee Poe, Jr.

Tetra Tech NUS, Inc.

900 Trail Ridge Road

Aiken, SC 29803 


\section{Table of Contents}

Section

Page

Introduction 1

Part 1. Regional Site Data Used to Determine Time-Dependent Release Data.................................... 3

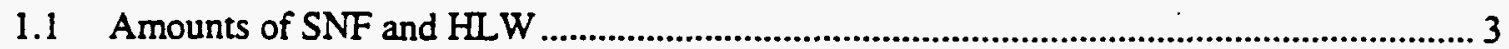

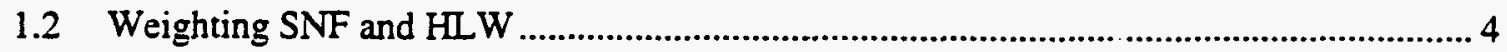

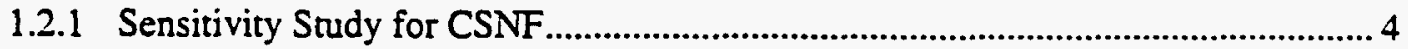

1.2.2 Curies of Americium and Plutonium Used in Regional Weighting ........................ 4

1.3 Determination of Regional Environmental Conditions Significant to Life of SNF or HLW 5

Part 2. Regional Site Data Used to Determine Underground Transport ............................................... 6

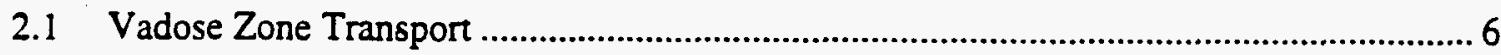

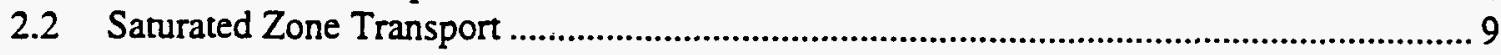

Part 3 Regional Site Data Used to Determine Surface Water Transport and Populations Using Surface Waters for Drinking.

References 14

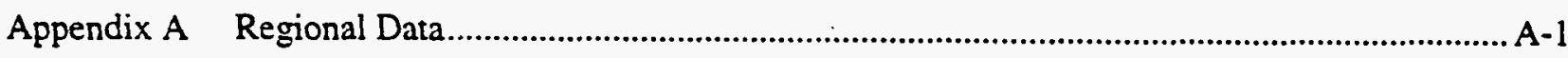

Appendix B Transport through Groundwater................................................................................ B-1

B.1 Water Flow Through the Vadose Zone ..................................................................... B-1

B.2 Water Flow Through the Saturated Zone ............................................................ B-3

Appendix C Site Data Used To Determine Surface Water Transport and Populations Using Surface Waters for Drinking

\section{List of Tables}

$\underline{\text { Table }}$

1-1 Amounts of spent nuclear fuel and high-level radioactive waste in each geographic region...

1-2 Curies of $\mathrm{Am}$ and $\mathrm{Pu}$ expected to be released over 10,000 years........................................ 5

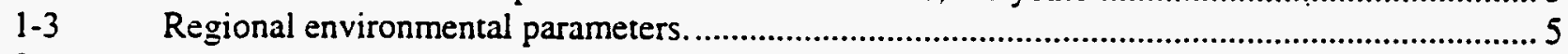

2.1-1 Transport times for radioactive nuclides in Region 1. ......................................................6 6

2.1-2 Transport times for radioactive nuclides in Region 2. .................................................. 7

2-1-3 Transport times for radioactive nuclides in Region 3. ................................................... 7

2-1-4 Transport times for radioactive nuclides in Region 4 ...................................................... 8

2-1-5 Transport times for radioactive nuclides in Region 5. ................................................. 8

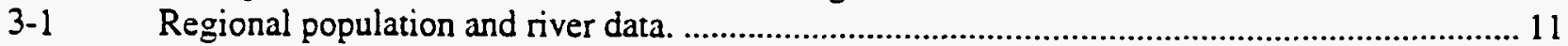

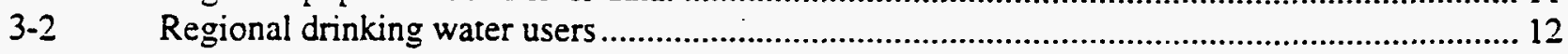




\section{Table of Contents (Continued)}

\section{List of Tables (Continued)}

Table

Page

A.1.1-1 Region 1 SNF and $\mathrm{HLW}$ inventory

A-1

A.1.1-2

Region 2 SNF and HLW inventory

A-2

A.1.1-3

Region 3 SNF and HLW inventory

A-2

A.1.1-4

Region 4 SNF and HLW inventory

A-3

A.1.1-5

Region 5 SNF and HLW inventory

A-3

A.1.2-1

Region $1 \mathrm{Am}-\mathrm{Pu}$ curies released in 10,000 years.

$A-4$

A.1.2-2

Region 2 Am-Pu curies released in 10,000 years

A-5

A.1.2-3

Region $3 \mathrm{Am}-\mathrm{Pu}$ curies released in 10,000 years

A.1.2-4

Region 4 Am-Pu curies released in 10,000 years

A-6

A.1.2-5

Region 5 Am-Pu curies released in 10,000 years

A-6

A.1.3-1

Region 1 environmental parameters

A-13

A.1.3-2 Region 2 environmental parameters

A.1.3-3 Region 3 environmental parameters

A.1.3-4 Region 4 environmental parameters

A-16

A-1-3-5 Region 5 environmental parameters

A-16

B.2.1-1

Physical data for vadose zone in Region 1

B-1

B.2.1-2

Physical data for vadose zone in Region 2

B-2

B.2.1-3

Physical data for vadose zone in Region 3

$B-2$

B. $2.1-4$

Physical data for vadose zone in Region 4

$B-3$

B.2.1-5

Physical data for vadose zone in Region 5

B. 2.2-1

Physical data for saturated zone in Region 1

B-4

B.2.2-2

Physical data for saturated zone in Region 2

B-5

B.2.2-3

Physical data for saturated zone in Region 3

B-6

B.2.2-4

B.2.2-5

C.3.1-1

C. $3.1-2$

Physical data for saturated zone in Region 4

B-7

Physical data for saturated zone in Region 5

Drinking water population (affected by degrading storage) in Region 1

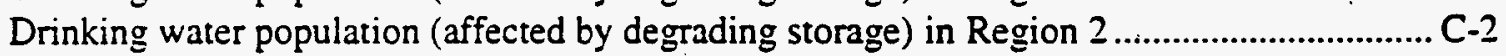

C. $3.1-3$

Drinking water population (affected by degrading storage) in Region 3

Drinking water population (affected by degrading storage) in Region 4

\section{List of Figures}




\section{Introduction}

In the Continued Storage Analysis Report (CSAR) (Reference 1), DOE decided to anayze the environmental consequences of continuing to s'ore the commerctal spent nuclear fuel (SNF) at 72 commercial nuclear power sites and DOE-owned spent nuclear fuel and high-level waste at five Department of Energy sites by region rather than by individual site. This analysis assumes that three commercial facilities pairs - Salem and Hope Creek, Fitzpatrick and Nine-Mile Point, and Dresden and Morris -- share common storage due to their proximity to each other. The five regions selected for this analysis are shown on Figure 1. Regions 1, 2, and 3 are the same as those used by the Nuclear Regulatory Commission in their regulatory oversight of commercial power reactors. NRC Region 4 was subdivided into two regions to more appropriately define the two different climates that exist in NRC Region 4.

A single hypothetical site in each region was assumed to store all the SNF and HLW in that region. Such a site does not exist and has no geographic location but is a mathematical construct for analytical purposes. To ensure that the calculated results for the regional analyses reflect appropriate inventory, facility and material degradation, and radionuclide transport, the waste inventories, engineered barriers, and environmental conditions for the hypothetical sites were developed from data for each of the existing sites within the given region. Weighting criteria to account for the amount and types of SNF and HLW at each site were used in the development of the environmental data for the regional site. such that the results of the analyses for the hypothetical site were representative of the sum of the results of each actual site if they had been modeled independently.

This report defines the actual site data used in development of this hypothetical site, shows how the individual site data was weighted to develop the regional site, and provides the weighted data used in the CSAR analysis. It is divided into Part 1 that defines time-dependent releases from each regional site, Part 2 that defines transport conditions through the groundwater, and Part 3 that defines transport through surface water and populations using the surface waters for drinking. 


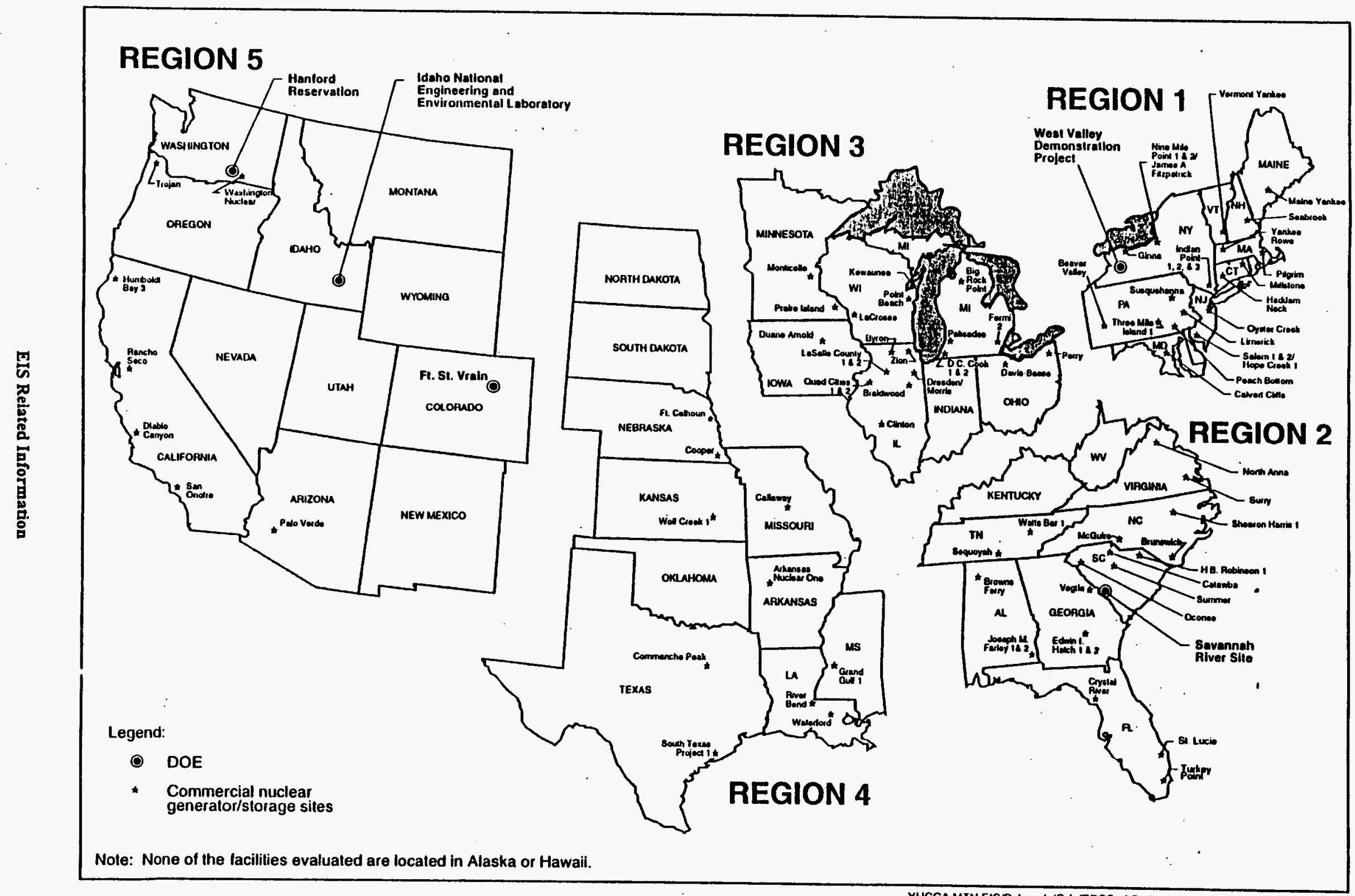




\section{Part 1 \\ Regional Site Data Used to \\ Determine Time-Dependent Release Data}

This part describes the regional site data used to determine time-dependent release data. The regional input data is provided in Appendix A. The table numbers of this section and of Appendix A are interlinked to simplify data evaluation. For example a single table in Part 1 provides data for all regions. Five linked tables in Appendix A provide more detailed data by region. The text in Part 1 explains how the Part 1 tables were developed. The text in Appendix A describes the source of the data in the tables in the Appendix.

\subsection{Amounts of SNF and HLW}

The left portion of Table 1-1 summarizes the regional location of the 63,000 metric tons heavy metal (MTHM) of commercial SNF considered in the No Action alternative. The right portion of the table gives the regional location of DOE's SNF and HLW. It also gives the major assumptions on storage configuration.

Table 1-1. Amounts of spent nuclear fuel and high-level radioactive waste in each geographic region.

\begin{tabular}{|c|c|c|c|c|c|c|c|c|c|}
\hline Region & $\begin{array}{l}\text { MTHM } \\
\text { in PWR }\end{array}$ & $\begin{array}{l}\text { MTHM } \\
\text { in BWR }\end{array}$ & $\begin{array}{l}\text { Total } \\
\text { MTHM }\end{array}$ & $\begin{array}{l}\text { MTHM } \\
\text { with } \\
\text { juvenile } \\
\text { clad } \\
\text { failure }\end{array}$ & $\begin{array}{l}\text { MTHM } \\
\text { with } \\
\text { stainiess } \\
\text { steel } \\
\text { cladding }\end{array}$ & $\begin{array}{l}\text { MTHM } \\
\text { surrogate } \\
\text { SNF }\end{array}$ & $\begin{array}{c}\text { Storage } \\
\text { configuration }\end{array}$ & $\begin{array}{l}\text { Canisters } \\
\text { of HLW }\end{array}$ & $\begin{array}{c}\text { Stornge } \\
\text { configuraion }\end{array}$ \\
\hline 1 & 7,179 & 9.652 & 16.830 & 16 & 412 & & & 300 & Surface cask \\
\hline 2 & 14.509 & 4.389 & $18.898^{\circ}$ & 19 & 0 & 28.6 & Surface cask & $6.022^{c}$ & $\begin{array}{c}\text { Subsuriace } \\
\text { vault }\end{array}$ \\
\hline 3 & 7.998 & 6.683 & 14.682 & 15 & 171 & & & & \\
\hline 4 & 5.330 & 1,839 & 7.170 & 7 & 0 & & & & \\
\hline 5 & 4,811 & 610 & 5.420 & 5 & 144 & $\begin{array}{r}2,290 \\
14\end{array}$ & 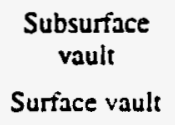 & 1.993 & $\begin{array}{l}\text { Subsurface } \\
\text { vault }\end{array}$ \\
\hline Totals & 39.827 & 23.173 & 63.000 & 62 & 727 & 2.333 & & 8.315 & \\
\hline
\end{tabular}

Three different time-dependent releases (called fluxes in the remainder of this report) were analyzed because of differences in packaging, material forms, etc as described in the CSAR (Reference 1). These are for commercial SNF (CSNF), DOE-SNF, and DOE-HLW.

The complete inventory of CSNF was considered to be PWR fuel even though approximately 37 percent are BWR fuel. This simplifying assumption minimized the calculational process and could be made because both PWR and BWR fuel follow the same deterioration process. The consequences of this simplification were corrected by convering the calculated flux (expressed as grams $\mathrm{UO}_{2}$ released for each 70-year lifetime period) to the appropriate radionuclide content using the source data for PWR and BWR fuel in the region. This makes the appropriate correction for differences in PWR and BWR fuels.

All of the DOE SNF is assumed to be surrogate Category 1 SNF (a metallic fuel with Zircaloy cladding that is primarily $\mathrm{N}$-Reactor fuel) to be consistent with the TSPA analysis. The total amount of DOE SNF was considered to be $2,333 \mathrm{MTU}$ and uses the average fission product content of Categories $1,4,5,6,8$, 
and 11. These values were summed from the site-specific data given in Appendix A. The DOE SNF flux were expressed as gU/70-year period.

The DOE-HLW inventory assumed 8,315 canisters of borosilicate glass HLW. lihe DUE-HLW flux were expressed as grams glass/70-year period.

The Base Case Inventory assumption for DOE HIL was that it included all of the HIW at SRS (6.022 canisters including surplus plutonium in Can-In-Canister), all at WVDP (300 canisters), and the remainder of the 8,315 canisters is from Hanford (1,993 canisters). HLW fluxes were expressed as grams glass/70-year period.

The assumptions on quantities of CSNF, DOE SNF, and DOE HLW and their chemical and radiological contents are based on Appendix A of the Yucca Mountain EIS (Reference 2). and on the Draft Analysis Bases for Yucca Mountain Monitored Repository Environmental Impact Statement (Reference 3).

\subsection{Weighting SNF \& HLW}

\subsubsection{SENSITIVITY STUDY FOR CSNF}

Reference 4 describes a sensitivity study that was done to determine which radionuclides contributed most to the population dose commitment from expected commercial SNF deterioration from long term exposure to the environment. In this sensitivity study, the commercial SNF waste package was assumed to deteriorate as discussed in Reference 5 and to begin releasing radionuclides to the environment in approximately 1,200 years and to continue releasing radionuclides until all of the SNF had dissolved. This sensitivity analysis determined the population dose commitment from drinking river water. The sensitivity was a comparison of all the flux of SNF released to the surface streams as soon as available to that if the flux was delayed 10 years and 100 years. This delay reflected impacts of transport through the groundwater causing the two delay times and its associated retention of some radionuclides on the soil column. The sensitivity study showed that most of the cumulative 10,000-year population dose commitment was due to plutonium and americium released from the SNF. The results were 99.47, 99.64, and 98.58 percent for zero delay, 10-year delay, and 100-year delay, respectively.

\subsubsection{CLRIES OF AMERICIUM AND PLUTONIUM USED IN REGIONAL WEIGHTING}

The total curies of americium and plutonium expected to be released over the 10.000 year period from each location were estimated based upon the following assumptions:

- Radionuclides Am-241, Am-242/242m, Am-243, Pu-238, Pu-239, Pu-240, Pu-241, and Pu-242 were considered. Radionuclides Am-241, Am-242/242m, Pu-238, and Pu-241 were found to be insignificant (in terms of curies released) and were ignored in further evaluations. This left Am-243, Pu-239, Pu-240 and Pu-242 which were carried into further evaluations.

- Releases from all commercial SNF clad with stainless steel or within the category of juvenile failure (0.1 percent of the Zircaloy clad SNF).

- Release of all the curies of Am-Pu contained in DOE-SNF Categories $1,4,6.8$, and 11 as provided in Table A.2.2-4 of Reference 2.

- One. eight, and two percent of the HLW at Hanford, SRS, and West Valley was respectively assumed to dissolve during the first 10.000 years. These estimates reflect amounts, packaging, storage, and environments at each site. 
Table 1-2 gives the curies of americium-plutonium calculated to be released by region and material type.

Table 1-2. Curies of Am and Pu expected to be released over 10,000 years.

\begin{tabular}{lcccccr}
\hline & \multicolumn{3}{c}{ Commercial SNF } & & & \\
\cline { 2 - 5 } Region & $\begin{array}{l}\text { Juvenile } \\
\text { failure }\end{array}$ & $\begin{array}{c}\text { Stainless steel } \\
\text { clad }\end{array}$ & DOE SNF & DOE HLW & Total \\
\hline Region 1 & 15,300 & 423,000 & NA & 75 & 438,000 \\
Region 2 & 18,900 & NA & 15,000 & 10,400 & 44,300 \\
Region 3 & 13,900 & 171,000 & NA & NA & 185,000 \\
Region 4 & 7,100 & NA & NA & NA & 7,100 \\
Region 5 & 5,400 & 150,000 & 675,000 & 69 & 830.000 \\
\% by Category & 4.0 & 49.4 & 45.9 & 0.7 & \\
\hline NA = not applicable; that particular material is not present in that region. &
\end{tabular}

\subsection{Determination of Regional Environmental Conditions Significant to Life of SNF or HLW}

The total curies of Am-243, Pu-239, Pu-240 and Pu-242 expected to be released over the 10,000-year period of analysis were used as the parameter to weight the environmental conditions within the region. For each site in a region, each environmental parameter (see Table 1-3), was multiplied by the total curies of americium-plutonium released at that site. The results for each parameter and site in a region were summed to get a region total for each environmental parameter. Each total was divided by the total curies of americium and plutonium in the region to determine the average value for each environmental parameter in each region. The curies of americium-plutonium considered to be released from each site were multiplied by the environmental parameter for that site then they were summed. That sum was divided by the sum of curies of americium-plutonium expected to be released within 10,000 years to get the weighted environmental values.

The environmental parameters determined for each region are shown in Table 1-3.

Table 1-3. Regional environmental parameters.

\begin{tabular}{|c|c|c|c|c|c|c|c|c|}
\hline \multirow[b]{2}{*}{ Region } & \multirow[b]{2}{*}{$\begin{array}{c}\text { Concrete } \\
\text { cask life, } \\
\text { yr. }\end{array}$} & \multirow[b]{2}{*}{$\begin{array}{l}\text { Precipitation } \\
\text { rate, } \\
\text { in/yr. }\end{array}$} & \multirow[b]{2}{*}{$\begin{array}{c}\text { Rain } \\
\text { days. } \\
\text { \% of } y r .\end{array}$} & \multirow[b]{2}{*}{$\begin{array}{l}\text { Total wet } \\
\text { days, } \\
q_{c} \text { of yr. }\end{array}$} & \multicolumn{3}{|c|}{ Precipitation chemistry } & \multirow[b]{2}{*}{$\begin{array}{c}\text { Average } \\
\text { temperature } \\
0_{\mathrm{F}}\end{array}$} \\
\hline & & & & & $\mathrm{pH}$ & $\begin{array}{l}\mathrm{Cl}^{2}, \\
\text { wt } \%\end{array}$ & $\begin{array}{l}\mathrm{SO}_{3}{ }^{\circ}, \\
\text { wt. } \%\end{array}$ & \\
\hline Region 1 & 95 & 42.2 & 30.2 & 30.8 & 4.4 & $6.9 \times 10^{-5}$ & $1.5 \times 10^{-4}$ & 51.7 \\
\hline Region 2 & 704 & 52.2 & 29.3 & 53.9 & 4.7 & $3.9 \times 10^{-5}$ & $9.0 \times 10^{-5}$ & 63.1 \\
\hline Region 3 & 72 & 32.5 & 32.9 & 41.8 & 4.7 & $1.6 \times 10^{-5}$ & $2.4 \times 10^{-1}$ & 49.8 \\
\hline Region 4 & 749 & 42.4 & 30.8 & 49.2 & 4.6 & $3.5 \times 10^{-5}$ & $1.1 \times 10^{-4}$ & 61.9 \\
\hline Region 5 & 3.530 & 10.5 & 23.6 & 23.7 & 5.3 & $2.1 \times 10^{-5}$ & $2.5 \times 10^{-5}$ & 54.9 \\
\hline
\end{tabular}




\section{Part 2 \\ Regional Site Data Used to Determine Underground Transport}

This part describes the ground water parameters used to calculate the delay times encountered in transport of radionuclides between the location of continued storage sites and surface water that could potentially reach populations. The information is divided into two subsections: vadose zone and saturated zone. As described in Part 1 the information in this section is calculated flow parameters showing times, in years, for water and plutonium to flow from the point of release to the Saturated zone or to the point of discharge to surface water.

In this part of the report there is one table for each region where continued storage is assumed.

Appendix $B$ also has five tables; one for each region. Each of the Appendix tables shows the site-specific data from each region. The text in Par 2 discusses how Part 2 tables were developed. The text associated with Appendix B provides the source of the data in the tables in the Appendix.

\subsection{Vadose Zone Transport}

The calculated flow time for water and plutonium are given in Tables 2.1-1 through 2.1-5. These calculated values describe the times required for flow of these materials through the vadose zone at each storage location and is used, as appropriate. Water and plutonium transport in these tables are used as examples of how the data are used as described in Reference 9. These flow times are based on the sitespecific data given in Appendix B.

Table 2.1-1. Transport times for radioactive nuclides in Region 1.

\begin{tabular}{|c|c|c|c|c|c|c|c|c|}
\hline \multirow[b]{2}{*}{ Region } & \multirow[b]{2}{*}{ Site } & \multirow[b]{2}{*}{ Fuel type } & \multirow[b]{2}{*}{$\begin{array}{c}\text { MEPAS } \\
\mathrm{Kd} \text { for Pu, } \\
\mathrm{ml} / \mathrm{g}\end{array}$} & \multicolumn{2}{|c|}{ Vadose zone } & \multicolumn{2}{|c|}{ Saturated zone } & \multirow{2}{*}{$\begin{array}{c}\text { Combined } \\
\text { total Pu } \\
\text { flow time } \\
\text { Vad. + Sat., } \\
\text { years } \\
\end{array}$} \\
\hline & & & & $\begin{array}{c}\text { Water } \\
\text { flow time, } \\
\text { years }\end{array}$ & $\begin{array}{l}\text { Pu flow } \\
\text { time, } \\
\text { years }\end{array}$ & $\begin{array}{c}\text { GW travel } \\
\text { time, } \\
\text { years }\end{array}$ & $\begin{array}{l}\text { Pu flow } \\
\text { time, } \\
\text { years }\end{array}$ & \\
\hline 1 & Haddam Neck & PWR & 10 & 0.7 & 47 & 1.3 & 96 & 143 \\
\hline 1 & Millstone & PWR \& BWR & 10 & 1.3 & 94 & 14.3 & 1.094 & 1,188 \\
\hline 1 & Salem/Hope Creek & PWR \& BWR & 10 & 4.0 & 282 & 7.2 & 554 & 836 \\
\hline 1 & Pilgrim & BWR & 10 & 3.6 & 258 & 1.3 & 96 & 354 \\
\hline 1 & Seabrook & PWR & 100 & 2.8 & 1,369 & 2.7 & 204 & $1: 573$ \\
\hline 1 & Maine Yankee & PWR & 10 & 0.8 & 59 & 5.8 & 443 & 501 \\
\hline 1 & Calven Cliffs & PWR & 100 & 0.8 & 327 & 5.7 & 3.344 & 3.671 \\
\hline 1 & Oyster Creek & BWR & 10 & 0.8 & 56 & 2.6 & 201 & 257 \\
\hline 1 & $\begin{array}{l}\text { Fitzparrick/Nine Mile } \\
\text { Point }\end{array}$ & BWR & 100 & 0.7 & 273 & 12.5 & 953 & 1,226 \\
\hline 1 & Ginna & PWR & 100 & 3.0 & 1,139 & 8.6 & 655 & 1.794 \\
\hline 1 & Indian Point & PWR \& BWR & 10 & 0.7 & 47 & 5.7 & 433 & 480 \\
\hline 1 & Yankee-Rowe & PWR & 10 & 1.3 & 73 & 1.1 & 612 & 685 \\
\hline 1 & Beaver Valley & PWR & 100 & 2.6 & 1.256 & 56.1 & 4.295 & 5,552 \\
\hline 1 & Limerick & BWR & 0 & 0.4 & 0 & 10.0 & 10 & 10 \\
\hline 1 & Peach Bottom & BWR & 10 & 0.5 & 33 & 1.8 & $1+1$ & 174 \\
\hline 1 & Susquehanna & BWR & 100 & 4.4 & 2,094 & 12.9 & 13 & 2.107 \\
\hline 1 & Three Mile Island & PWR & 10 & 0.7 & 47 & 0.3 & 26 & 73 \\
\hline 1 & Vermont Yankee & BWR & 10 & 0.8 & 43 & 1.1 & 65 & 108 \\
\hline 1 & $\begin{array}{l}\text { West Valley Demo } \\
\text { Project }\end{array}$ & DOE HLW & 10 & 0.5 & 43 & 32.2 & $5 .+41$ & 5,484 \\
\hline
\end{tabular}


Table 2.1-2. Transport times for radioactive nuclides in Region 2.

\begin{tabular}{|c|c|c|c|c|c|c|c|c|}
\hline \multirow[b]{2}{*}{ Region } & \multirow[b]{2}{*}{ Site } & \multirow[b]{2}{*}{ Fuel type } & \multirow[b]{2}{*}{$\begin{array}{c}\text { MEPAS } \\
\mathrm{Kd} \text { for Pu, } \\
\mathrm{ml} / \mathrm{g}\end{array}$} & \multicolumn{2}{|c|}{ Vadose zone } & \multicolumn{2}{|c|}{ Saturated zone } & \multirow{2}{*}{$\begin{array}{c}\text { Combined } \\
\text { total Pu } \\
\text { flow time } \\
\text { Vad. + Sat.. } \\
\text { vears } \\
\end{array}$} \\
\hline & & & & $\begin{array}{c}\text { Water } \\
\text { flow time, } \\
\text { years }\end{array}$ & $\begin{array}{l}\text { Pu flow } \\
\text { time. } \\
\text { years }\end{array}$ & $\begin{array}{c}\text { GW travel } \\
\text { time, } \\
\text { years } \\
\end{array}$ & $\begin{array}{l}\text { Pu flow } \\
\text { time. } \\
\text { vears }\end{array}$ & \\
\hline 2 & Browns Ferry & BWR & 10 & 0.6 & 35 & 5.6 & 426. & 461 \\
\hline 2 & Farley & PWR & 10 & 2.2 & 153 & 26.3 & 2.193 & 2.346 \\
\hline 2 & Crystal River & PWR & 100 & 0.8 & 327 & 5.0 & 421 & 749 \\
\hline 2 & St. Lucie & PWR & 100 & 10.3 & 4,944 & 90.1 & 6,896 & $11.8+0$ \\
\hline 2 & Turkey Point & PWR & 10 & 3.8 & 268 & 28.3 & 2.167 & 2,435 \\
\hline 2 & Hatch & BWR & 10 & 1.3 & 70 & 77.9 & 5,960 & 6.030 \\
\hline 2 & Vogtle & PWR & 10 & 3.2 & 174 & 24.1 & 1,461 & 1.635 \\
\hline 2 & Brunswick & PWR & 250 & 2.6 & 1,957 & 255.1 & 312,596 & 314,552 \\
\hline 2 & Catawba & PWR & 100 & 1.3 & 491 & 3.3 & 1.950 & 2,441 \\
\hline 2 & Harris & PWR \& BWR & 100 & 1.1 & 511 & 11.0 & 848 & 1.359 \\
\hline 2 & McGuire & PWR & 100 & 1.7 & 655 & 9.5 & 695 & 1,350 \\
\hline 2 & Oconee & PWR & 250 & 3.6 & 2,739 & 6.9 & 4,038 & 6.777 \\
\hline 2 & Robinson & PWR & 10 & 1.4 & 96 & 35.2 & 2,692 & 2,787 \\
\hline 2 & Summer & PWR & 100 & 2.5 & 982 & 11.2 & 11 & 993 \\
\hline 2 & Sequoyah & PWR & 100 & 3.8 & 1,473 & 10.8 & 5.782 & 7,255 \\
\hline 2 & Watts Bar & PWR & 250 & 2.4 & 1,800 & 5.8 & 7,153 & 8,953 \\
\hline 2 & North Anna & PWR & 100 & 0.8 & 327 & 5.6 & 3.269 & 3,597 \\
\hline 2 & Surry & PWR & 100 & 2.5 & 982 & 9.6 & 5.627 & 6,609 \\
\hline 2 & Savannah River Site & DOE SNF & 10 & 2.9 & 187 & 7.9 & 700 & 887 \\
\hline 2 & Savannah River Site & DOE HLW & 10 & 2.9 & 187 & 12.7 & 1.120 & 1.306 \\
\hline
\end{tabular}

Table 2-1-3. Transport times for radioactive nuclides in Region 3.

\begin{tabular}{|c|c|c|c|c|c|c|c|c|}
\hline \multirow[b]{2}{*}{ Region } & \multirow[b]{2}{*}{ Site } & \multirow[b]{2}{*}{ Fuel type } & \multirow[b]{2}{*}{$\begin{array}{c}\text { MEPAS } \\
\mathrm{Kd} \text { for } \mathrm{Pu} \text {, } \\
\mathrm{ml} / \mathrm{g}\end{array}$} & \multicolumn{2}{|c|}{ Vadose zone } & \multicolumn{2}{|c|}{ Saturated zone } & \multirow{2}{*}{$\begin{array}{c}\text { Combined } \\
\text { total Pu } \\
\text { flow time } \\
\text { Vad. + Sat.. } \\
\text { years }\end{array}$} \\
\hline & & & & $\begin{array}{c}\text { Water } \\
\text { flow time. } \\
\text { years }\end{array}$ & $\begin{array}{l}\text { Pu flow } \\
\text { time. } \\
\text { years }\end{array}$ & $\begin{array}{c}\text { GW travel } \\
\text { time, } \\
\text { years }\end{array}$ & $\begin{array}{l}\text { Pu flow } \\
\text { time. } \\
\text { years }\end{array}$ & \\
\hline 3 & Duane Amold & BWR & 10 & 1.5 & 104 & 24.8 & 1,896 & 2.000 \\
\hline 3 & Braidwood & PWR & $10^{\circ}$ & 1.1 & 80 & $41+.7$ & 31.735 & 31,815 \\
\hline 3 & Byron & PWR & 100 & 0.8 & 315 & 35.7 & 23,431 & 23,747 \\
\hline 3 & Clinton & BWR & 10 & 0.5 & 32 & 1.3 & 99 & 131 \\
\hline 3 & Dresden/Morris & PWR \& BWR & 100 & 0.5 & 210 & 26.5 & 2.028 & 2.238 \\
\hline 3 & Lasalle County & BWR & 100 & 1.4 & 526 & 15.4 & 934 & 1.460 \\
\hline 3 & Quad Cities & BWR & 10 & 2.6 & 184 & 2.1 & 163 & 347 \\
\hline 3 & Zion & PWR & 10 & 1.7 & 123 & 10.2 & 779 & 902 \\
\hline 3 & Big Rock Point & BWR & 10 & 0.7 & 49 & 15.4 & 15 & 65 \\
\hline 3 & Cook & PWR & 10 & 1.3 & 92 & 2.0 & 156 & 248 \\
\hline 3 & Enrico Fermi & BWR & 100 & 2.7 & 1.051 & 9.0 & 9 & 1.060 \\
\hline 3 & Palisades & PWR & 10 & 13.9 & 757 & 13.9 & 846 & 1.603 \\
\hline 3 & Monticello & BWR & 10 & 1.7 & 123 & 15.4 & 1,178 & 1,301 \\
\hline 3 & Prairie Island & PWR & 10 & 13.9 & 983 & 2.0 & 156 & 1.139 \\
\hline 3 & Davis-Besse & PWR & 250 & 2.0 & 1.525 & 33.7 & 34 & 1.559 \\
\hline 3 & Perry & BWR & 100 & 2.8 & 1.329 & 75.0 & $\$ 4.023$ & 45.352 \\
\hline 3 & Kewaunee & PWR & 10 & 0.9 & 61 & 15.4 & 1.178 & 1.240 \\
\hline 3 & Lacrosse & BWR & 10 & 0.9 & 61 & 1.9 & 147 & 208 \\
\hline 3 & Point Beach & PWR & 10 & 5.6 & 303 & 3.1 & 191 & 493 \\
\hline
\end{tabular}


Table 2-1-4. Transport times for radioactive nuclides in Region 4.

\begin{tabular}{|c|c|c|c|c|c|c|c|c|}
\hline \multirow[b]{2}{*}{ Region } & \multirow[b]{2}{*}{ Site } & \multirow[b]{2}{*}{ Fuel type } & \multirow[b]{2}{*}{$\begin{array}{c}\text { MEPAS } \\
\mathrm{Kd} \text { for Pu, } \\
\mathrm{mV} / \mathrm{g}\end{array}$} & \multicolumn{2}{|c|}{ Vadose zone } & \multicolumn{2}{|c|}{ Saturated zone } & \multirow{2}{*}{$\begin{array}{c}\text { Combined } \\
\text { total Pu } \\
\text { flow time } \\
\text { Vad. + Sat. } \\
\text { years } \\
\end{array}$} \\
\hline & & & & $\begin{array}{c}\text { Water } \\
\text { flow time. } \\
\text { years }\end{array}$ & $\begin{array}{l}\text { Pu flow } \\
\text { time. } \\
\text { years }\end{array}$ & $\begin{array}{c}6 \mathrm{G} \text { travel } \\
\text { time. } \\
\text { years } \\
\end{array}$ & $\begin{array}{l}\text { Pu flow } \\
\text { time. } \\
\text { vears } \\
\end{array}$ & \\
\hline 4 & Arkansas Nuclear One & PWR & 100 & 0.8 & 327 & 958.7 & 515,513 & 515.840 \\
\hline 4 & Wolf Creek & PWR & 100 & 4.0 & 1,917 & 575.8 & 337.951 & 339.868 \\
\hline 4 & River Bend & BWR & 10 & 4.3 & 306 & 9.3 & 715 & 1.021 \\
\hline 4 & Waterford & PWR & 100 & 4.7 & 1,800 & & & 1,800 \\
\hline 4 & Callaway & PWR & 100 & 1.8 & 683 & 112.4 & 8.605 & 9.288 \\
\hline 4 & Grand Gulf & BWR & 100 & 5.9 & 2.291 & 16.2 & 1,240 & 3,531 \\
\hline 4 & Cooper & BWR & 100 & 1.1 & 548 & 3.9 & 301 & 848 \\
\hline 4 & Fort Calhoun & PWR & 100 & 0.2 & 110 & 4.6 & 350 & 459 \\
\hline 4 & Comanche Peak & PWR & 100 & 4.6 & 2,190 & & & 2.190 \\
\hline 4 & South Texas & PWR & 10 & 7.1 & 386 & 68.8 & 5.267 & 5.653 \\
\hline
\end{tabular}

Table 2-1-5. Transport times for radioactive nuclides in Region 5.

\begin{tabular}{|c|c|c|c|c|c|c|c|c|}
\hline \multirow[b]{2}{*}{ Region } & \multirow[b]{2}{*}{ Site } & \multirow[b]{2}{*}{ Fuel type } & \multirow[b]{2}{*}{$\begin{array}{c}\text { MEPAS } \\
\mathrm{Kd} \text { for Pu, } \\
\mathrm{m} / \mathrm{g}\end{array}$} & \multicolumn{2}{|c|}{ Vadose zone } & \multicolumn{2}{|c|}{ Sarurated zone } & \multirow{2}{*}{$\begin{array}{c}\text { Combined } \\
\text { total Pu } \\
\text { flow time } \\
\text { Vad. + Sat. } \\
\text { years }\end{array}$} \\
\hline & & & & $\begin{array}{c}\text { Water } \\
\text { flow time, } \\
\text { years }\end{array}$ & $\begin{array}{l}\text { Pu flow } \\
\text { time, } \\
\text { years }\end{array}$ & $\begin{array}{c}\text { GW travel } \\
\text { time. } \\
\text { vears }\end{array}$ & $\begin{array}{l}\text { Pu flow } \\
\text { time. } \\
\text { years }\end{array}$ & \\
\hline 5 & Palo Verde & PWR & 10 & 4.8 & 260 & & 0 & 260 \\
\hline 5 & Diablo Canyon & PWR & 100 & 2.9 & 1,717 & 1.7 & 1,007 & 2.724 \\
\hline 5 & Humboldt Bay & BWR & 10 & 0.9 & 64 & 1.8 & 137 & 201 \\
\hline 5 & Rancho Seco & PWR & 10 & 53.7 & 3,802 & & 0 & 3.802 \\
\hline 5 & San Onofre & PWR & 0 & 14.3 & 14 & 2.3 & 1,353 & 1,367 \\
\hline 5 & Trojan & PWR & 100 & 3.5 & 1.367 & 5.6 & 3,258 & 4,625 \\
\hline 5 & Washington Nuclear & BWR & 10 & 61.8 & 4,373 & 6.9 & 527 & 4.900 \\
\hline 5 & Hanford & DOE SNF & 10 & 73.1 & 4,740 & 20.3 & 1.551 & 6,292 \\
\hline 5 & Hanford & DOE HLW & 10 & 73.1 & 4.740 & 20.3 & 1.551 & 6,292 \\
\hline 5 & $\begin{array}{l}\text { Idaho National Engr } \\
\text { Laboratory }\end{array}$ & DOE SNF & 10 & 22.2 & 1,085 & 173.7 & 25.284 & 26.370 \\
\hline 5 & Fort St Vrain & DOE SNF & 10 & 6.2 & 437 & 39.9 & 3.050 & 3.488 \\
\hline
\end{tabular}

The flow times in the vadose zone were calculated from the site-specific storage parameters given in Appendix B Tables B.2.1-1, B.2.1-2, B.2.1-3, B.2.1-4, and B.2.1-5. Formulae are given below for these calculations:

Water flow time $(\mathrm{WFT})=(\mathrm{TV}) *(\mathrm{MC}) *(100) /(\mathrm{PR})$

Where:

WFT $=$ water flow time, yr.

$T V=$ thickness of vadose zone, feet.

$\mathrm{PR}=$ precipitation rate, $\mathrm{ft} / \mathrm{yr}$.

$\mathrm{MC}=$ moisture content of soil; Vol. $\%=$ average of soil porosity $(\mathrm{Vol} . \%)$ and field capacity (Vol. \%). 
Pu flow time $=\left[(\mathrm{WFT}) *(100 \mathrm{BD}) *\left(\mathrm{~K}_{\mathrm{d}}\right) /(\mathrm{MC})\right]+1$

Where:

Pu flow time expressed in years

$\mathrm{BD}=$ bulk density; $\mathrm{g} / \mathrm{cm}^{3}$

$\mathrm{K}_{\mathrm{d}}=$ distribution coefficient; $\mathrm{ml} / \mathrm{g}$

Distribution coefficients for $\mathrm{Pu}$ in Tables 2.1-1 through 2.1-5 were 10,100, or 250 depending on the clay content of the soils (Reference 10 ). $A \mathrm{~K}_{d}$ of 10 assumes a clay content $<10 \%$; $10 n$ assumes between 10 and $29 \%$ clay; and 250 assumes soils with $>30 \%$ clay.

\subsection{Saturated Zone Transport}

The calculated flow times for water and plutonium through the saturated zone also are given in Tables 2.1-1 through 2.1-5. These calculated values describe the times for flow of these materials through the saturated zone to the point where they emerge into surface streams.

A general assumption was made that the storage locations were 1,600 feet from existing reactors and up gradient (groundwater) from the reactors. This 1,600 feet is the average present distance from the reactors to the independent spent fuel storage installations (ISFSI). The saturated groundwater flow rate across this 1,600 feet was assumed to be the same as the groundwater flow rate between the reactors and the point of groundwater emergence to surface streams (in Reference 11).

The flow times in the saturated zone were calculated from site-specific storage parameters given in the information in Appendix B Tables. Formulae are given below for these calculations:

Groundwater Water flow time $($ GWFT) $=(T D) /(G W V)$.

Where:

GWFT = groundwater flow time in years

TD = total distance from ISFSI to point of emergence of groundwater into surface waters, $\mathrm{ft}$.

$\mathrm{GWV}=$ groundwater velocity, $\mathrm{ft} / \mathrm{yr}$

- Where available, groundwater velocities assumed the groundwater velocities between the reactor and point of emergence into surface waters. These are given in column 10 of Tables B.2.2-1 through B.2.2-5 (Reference 11 ).

- Where velocities were not available it was estimated using engineering judgments of groundwater conditions considered to be typical.

Pu saturated flow time $=(G W V) *\left[(100 S B D) *\left(S K_{d}\right) /(S E P)+1\right]$ 
Where:

Pu flow time expressed in years

$\mathrm{SBD}=$ bulk density in the Sarurated zone; $\mathrm{g} / \mathrm{cm}^{3}$

$\mathrm{SK}_{d}=$ distribution coefficient in the saturated zone; $\mathrm{m}$ / $\mathrm{g}$. Depends upon the clay content of the soil and used Reference 10 (MEPAS value ranges).

SEP = effective porosity of saturated soils $(\mathrm{vol} \%)$ was estimated at $60 \%$ of the satarated zone . total soil porosity. 


\section{Part 3 \\ Regional Site Data Used to \\ Determine Surface Water Transport and Populations Using Surface Waters for Drinking}

Table 3-1 shows the total downstream (summed for each facility) population drinking water contaminated by facility degradation by region and the sum of the population using river water as a drinking water source divided by river flow (cfs) at each of these population centers (Sum Population/Flow). The values shown as the Sum of Population/River Flow consider the populations downstream uf each of the storage locations. Using this term simplifies the consequence calculations for each location by determining a single value that reflects the full range of affected populations and river flows for that storage location. This value corrects for stream flow increases as the rivers flow downstream. For example for the Duane Arnold commercial SNF location; degradation products from this SNF would enter the Cedar River and flow to the Gulf of Mexico via the Mississippi River. On this flow to the Gulf, the stream waters are used by thirty-six municipal water districts to supply drinking water to approximately 3 million users. At Duane Amold the Sum Population/Flow is 9.96 people per cfs. From this value and the 3 million drinking water population, one can calculate the mean river flow to be $310,000 \mathrm{cfs}$. This can be compared to the flow of the Cedar River near the site of 3,300 cfs and to the Mississippi River at the river mouth of 494,000 cfs. The consequence from the total population drinking water would be the same if the calculations use the sum of the product of each population group using the water times actual stream flow or if the total population and the mean river flow is used. Total populations and mean river flow were used in these calculations.

Table 3-1. Regional population and river data.

\begin{tabular}{lcccc} 
& \multicolumn{2}{c}{ Population affected } & \multicolumn{2}{c}{ Sum population/flow } \\
\cline { 2 - 5 } Region & Total & Weighted & Total & Weighted \\
Region 1 & $1.6 \times 10^{7}$ & $2.1 \times 10^{6}$ & $1.4 \times 10^{3}$ & $1.9 \times 10^{2}$ \\
Region 2 & $1.3 \times 10^{7}$ & $3.7 \times 10^{5}$ & $6.8 \times 10^{2}$ & $2.3 \times 10^{1}$ \\
Region 3 & $4.4 \times 10^{7}$ & $3.1 \times 10^{6}$ & $2.2 \times 10^{2}$ & $1.6 \times 10^{1}$ \\
Region 4 & $2.7 \times 10^{7}$ & $2.6 \times 10^{6}$ & $1.6 \times 10^{2}$ & $1.5 \times 10^{1}$ \\
Region 5 & $5.7 \times 10^{6}$ & $1.9 \times 10^{5}$ & $4.3 \times 10^{1}$ & $1.5 \times 10^{0}$ \\
Totals & $\mathrm{NA}$ & $8.3 \times 10^{6}$ & $\mathrm{NA}$ & $2.4 \times 10^{2}$ \\
\hline
\end{tabular}

The data for the individual storage locations in each region was summed to give a single region value. Those values are given columns 2 and 4 on Table 3-1. These values are used to calculate dose consequence in Reference 9. Table 3-1 also gives weighted Populations and Sum Population/Flow values for each region. These weighted values were determined, as described in Section 1-3, from the curies of americium and plutonium expected to be released times the value being weighted then dividing the sum of these calculations by the total curies released from the region. Since these values reflect only sites that impact drinking water users, sites that discharge to salt waters with no drinking water populations receive no weight. These weighted values then were used to determine the population dose commitment as described in Reference 9. 
Figure 2 shows the relationship of individual storage sites and the major waterways that will be affected as the materials stored degrade. As can be seen by comparing Figures 1 and 2, portions of the material degrading in Regions 1,2,3, and 5 discharge to the Mississippi River and flow to the Gulf of Mexico and affect drinking water populations in Region 4. Using the weighted values for population from Table 3-1 overestimate the national population affected by the degradation of the materials stored by double counting some of the populations. In an attempt to determine a number of individuals that would be exposed to SNF and HLW degradation products, the total drinking water file was combined and sorted by states then grouped into the five regions. This analysis is documented in Reference 12. Table 3-2 gives. the number of regional water drinkers and shows that 30.5 million people will be affected by this assumed SNF and HLW deterioration.

Table 3-2. Regional drinking water users

\begin{tabular}{cc}
\hline Region & Millions of water users \\
\hline 1 & 6.7 \\
2 & 5.3 \\
3 & 13.1 \\
4 & 5.3 \\
5 & 0.16 \\
Total in United States & 30.5 \\
\hline
\end{tabular}




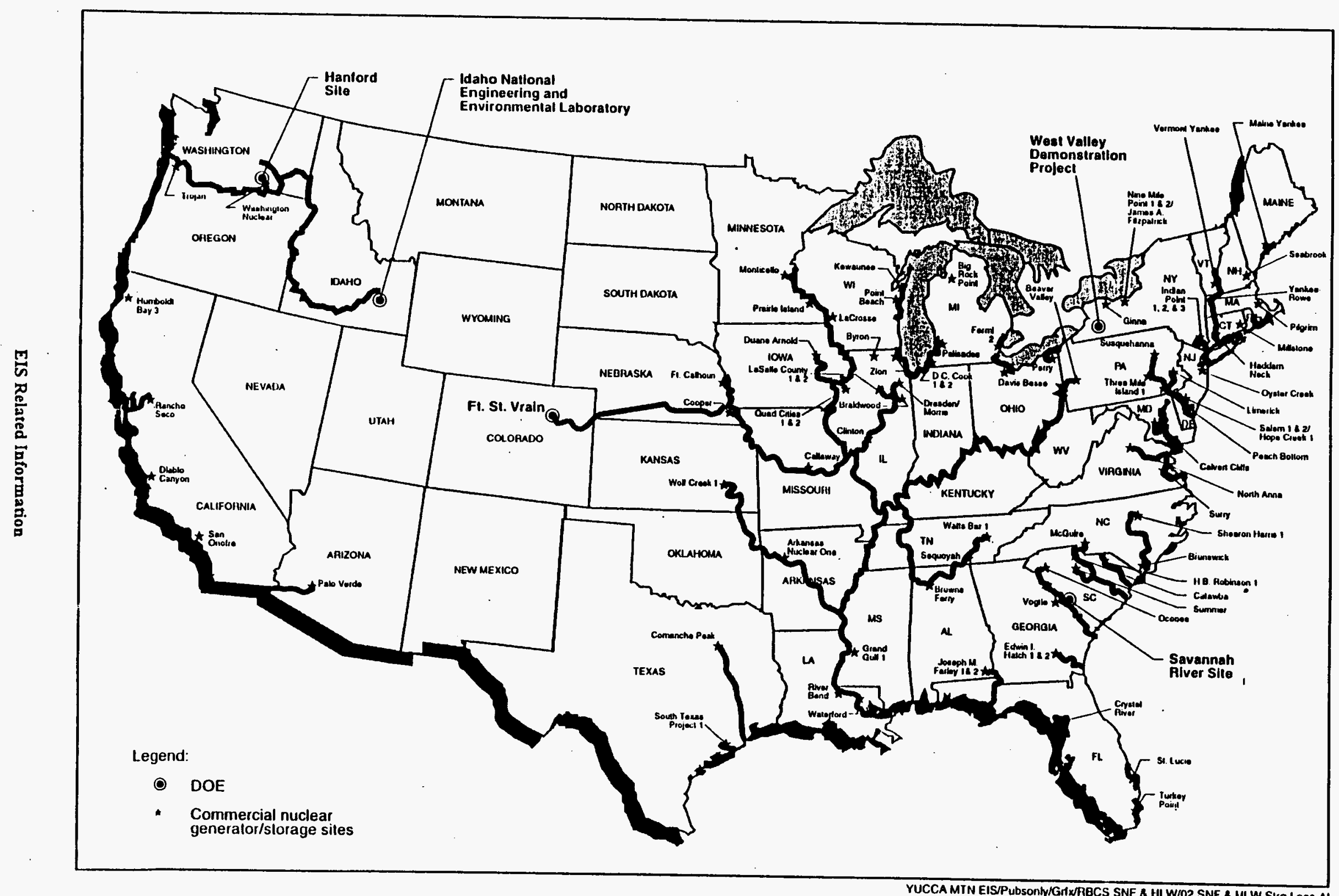

쫑 


\section{References}

Reference 1. "Draft Continued Storage Analysis Report", Revision OF, September 25, 1998.

Reference 2. Appendix A, "Spent Nuclear Fuel and High-Level Radioactive Waste Inventory and Characteristics", Revision OA, May 4, 1998.

Reference 3. "Draft Analysis Bases for Yucca Mountain Repository Environmental Impact Statement", Revision OF, August 28, 1998.

Reference 4. "Sensitivity Study of Effects on Population Dose Commitment of Flow-Time Through the Vadose-Saturated Zones, by W. L. Poe, Tetra Tech NUS, Aiken, SC, July 1998.

Reference 5. BPNWD (Battelle Pacific Northwest Division), 1998, “No Action Alternative Analysis for Commercial Spent Nuclear Fuel, DOE High-Level Waste, and DOE Spent Nuclear Fuel - Source Term Estimates", Richland, WA, May 1998.

Reference 6. "Waste Quantities, Mix and Throughput Study Report", Table F-1. Document Number \#B00000000-01717-5705-00059, Revision 01.

Reference 7. "National Weather Conditions Affecting Long-Term Degradation of Commercial Spent Nuclear Fuel and DOE Spent Nuclear Fuel and High-Level Waste," by W. L. Poe and P. F. Wise, Tetra Tech NUS, Inc., Aiken, SC, October 1998.

Reference 8. "Long term Degradation of Concrete Presently Used for Storage of Spent Nuclear Fuel and High-Level Waste," Rev. 1, by W. L. Poe, Tetra Tech NUS, Inc., Aiken, SC, October 1998.

Reference 9. "Radionuclide Transport and Dose Commitment from Drinking Water from Continued Storage and Degradation of Spent Nuclear Fuel and High-Level Waste Materials Under Loss of Institutional Control", by A. L. Toblin, Tetra Tech NUS, Gathersburg, MD, October 1998.

Reference 10. "Multimedia Environmental Pollutant Assessment System (MEPAS) Application Guidance, Volume 1 - User Guide," by J. G. Droppo et al., PNL-7216, Pacific Northwest Laboratory, Richland, WA.

Reference 11. "Groundwater Transport Conditions Near Commercial Reactor and DOE Sites", by A. T. Jenkins, Tetra Tech NUS, Oak Ridge, TN.

Reference 12. "Regional Drinking Water Population by State." By R. G. Davis, Tetra Tech NUS, Inc., Aiken, SC, November 1998.

Reference 13. "Population Affected from Continued Storage and Degradation of Spent Nuclear Fuels and High-Level Waste," by D. S. Sinkowski, Tetra Tech NUS. Inc., Aiken, SC, October 1998. 


\section{Appendix A Regional Data}

The original sources of the data used in Tables A.1.1-1, A.1.1-2, A.1.1-3, A.1.1-4, and A.1.1-5 are described below:

- Column 1 is the name of the site being used for storage of materials scheduled. These tables assume that the materials remain at the sites for the 10,000-year analysis period. The data for commercial SNF came from the YM EIS Appendix A (Reference 3), Table A.2.1-1. The analysis assumes the DOE SNF is surrogate $N$-Reactor fuel from categories $1,4,5,6,8$, and 11 from YM EIS Appendix A Table A.2.2-2. The location of the DOE HLW was obtained from Reference 6.

- Column 2 data came from YM EIS Appendix A Table A.2.1-1.

- Column 3 is a near-by city with meteorological data. This data was used in Reference 7 for calculating concrete degradation.

- Column 4 is the State where the storage area is located.

- Column 5 contains the amounts of CSNF from YM EIS Appendix A Table A.2.1-4.

- Column 6 is the difference between column 5 and 7.

- Column 7 data was provided by Joe Zeigler in a May 28, 1998 FAX. Data was confirmed by Joe Rivers and Dave Zabranski (DOE-RW)

- Column 8 is Juvenile Zircaloy failures which were calculated as (0.001)X(MTHM of Zircaloy-clad SNF).

Table A.1.1-1. Region 1 SNF and HLW inventory.

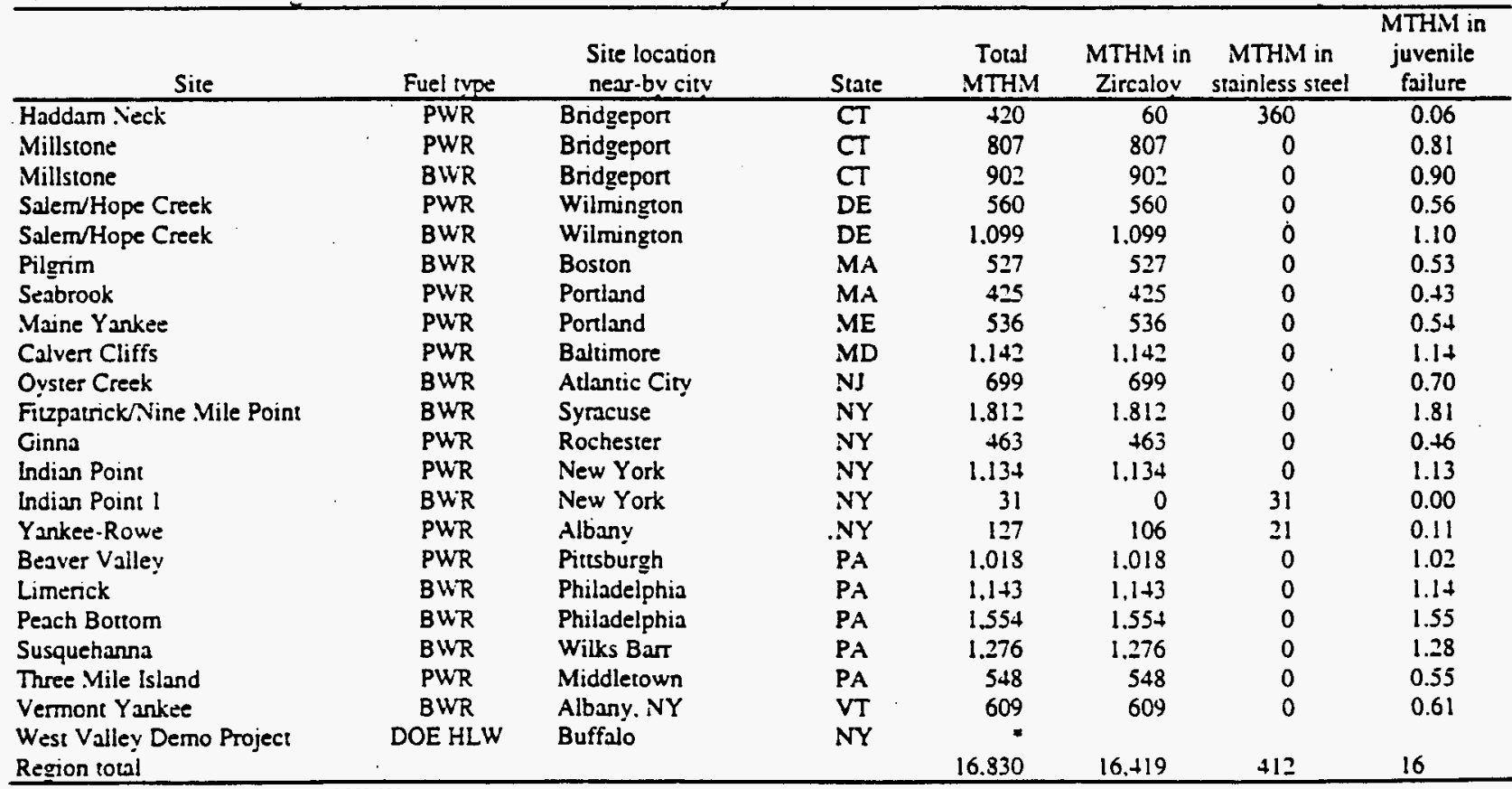

- See Tabie $1-1$ for quantity of HLW. 
Table A.1.1-2. Region 2 SNF and HLW inventory.

\begin{tabular}{|c|c|c|c|c|c|c|c|}
\hline Site & Fuel type & $\begin{array}{l}\text { Site location } \\
\text { near-by city }\end{array}$ & State & $\begin{array}{c}\text { Total } \\
\text { MTHM }\end{array}$ & $\begin{array}{l}\text { MTHM in } \\
\text { Zircaloy }\end{array}$ & $\begin{array}{c}\text { MTHM in } \\
\text { stainless steel }\end{array}$ & $\begin{array}{c}\text { MTHM in } \\
\text { juvenile } \\
\text { failure }\end{array}$ \\
\hline Browns Ferry & BWR & Huntsville & AL & 1,932 & -1.932 & 0 & 1.93 \\
\hline Farley & PWR & Montgomery & AL & 1.174 & 1.174 & 0 & 1.17 \\
\hline Crystal River & PWR & Tampa & FL & 512 & .512 & 0 & 0.51 \\
\hline St. Lucie & PWR & West Palm Beach & FL & 1.020 & 1.020 & 0 & 1.02 \\
\hline Turkey Point & PWR & Miami & FL & 1.074 & 1.074 & 0 & 1.07 \\
\hline Hatch & BWR & Macon & GA & 1,446 & 1.446 & 0 & 1.45 \\
\hline Vogtle & PWR & Augusts & GA & 1.080 & 1.080 & 0 & 1.08 \\
\hline Brunswick & PWR & Wilmington & $\mathrm{NC}$ & 137 & 137 & 0 & 0.14 \\
\hline Brunswick & BWR & Wilmington & NC & 759 & 759 & 0 & 0.76 \\
\hline Canawba & PWR & Charlotte & NC & 1,148 & 1.148 & 0 & 1.15 \\
\hline Harris & PWR & Raleigh & NC & 498 & 498 & 0 & 0.50 \\
\hline Harris & BWR & Raleigh & NC & 252 & 252 & 0 & 0.25 \\
\hline MeGuire & PWR & Charlone & NC & 1.439 & 1.439 & 0 & 1.4 \\
\hline Oconee & PWR & Greenville & sc & 1.865 & 1.865 & 0 & 1.87 \\
\hline Robinson & PWR & Columbia & SC & 384 & 384 & 0 & 0.38 \\
\hline Summer & PWR & Sparanburg & SC & 526 & 526 & 0 & 0.53 \\
\hline Sequoyah & PWR & Chartanooga & $\mathbf{T N}$ & 1,023 & 1.023 & 0 & 1.02 \\
\hline Warts Bar & PWR & Chattanooga & $T N$ & 251 & 251 & 0 & 0.25 \\
\hline Nornh Anna & PWR & Richmond & VA & 1.184 & 1,184 & 0 & 1.18 \\
\hline Surry & PWR & Norfolk & VA & 1.194 & 1.194 & 0 & 1.19 \\
\hline Savannah River Site & DOE-SNF & Augusta & GA & - & . & & \\
\hline Savannah River Site & DOE-HLW & Augusta & GA & $\bullet$ & & & \\
\hline Region total & & & & 18.898 & 18.898 & 0 & 19 \\
\hline
\end{tabular}

*See Table 1-1 for quantity of DOE-SiNF and DOE-HLW

Table A.1.1-3. Region 3 SNF and HLW inventory.

\begin{tabular}{|c|c|c|c|c|c|c|c|}
\hline Site & Fuel type & $\begin{array}{l}\text { Site location } \\
\text { near-by city }\end{array}$ & State & $\begin{array}{c}\text { Total } \\
\text { MTHM }\end{array}$ & $\begin{array}{l}\text { MTHM in } \\
\text { Zirealoy }\end{array}$ & $\begin{array}{l}\text { MTHM in } \\
\text { stainiess steel }\end{array}$ & $\begin{array}{c}\text { MTHM in } \\
\text { juvenile } \\
\text { failure }\end{array}$ \\
\hline Duane Amold & BWR & Des Moines & IA & 467 & 467 & 0 & 0.47 \\
\hline Braidwood & PWR & Peoria & IL & 1.029 & 1,029 & 0 & 1.03 \\
\hline Byron & PWR & Rockford & IL & 1,068 & 1.068 & 0 & 1.07 \\
\hline Clinton & BWR & Springfield & II. & 477 & 477 & 0 & 0.48 \\
\hline Dresden/Morris & BWR & Peoria & II & 2.013 & 2.013 & 0 & 2.01 \\
\hline Dresden/Morris & PWR & Peoria & II & 133 & 0 & 133 & 0.00 \\
\hline Lasalle County & BWR & Peoria & IL & 952 & 952 & 0 & 0.95 \\
\hline Quad Cities & BWR & Moline & II. & 1,277 & 1,277 & 0 & 1.28 \\
\hline Zion & PWR & Chicago & $\mathbb{L}$ & 1,052 & 1.052 & 0 & 1.05 \\
\hline Big Rock Point & BWR & Alpena & MI & 58 & 58 & 0 & 0.06 \\
\hline Cook & PWR & South Bend & $\mathbf{N}$ & $1,+33$ & 1.433 & 0 & 1.43 \\
\hline Enrico Fermi & BWR & Detroit & MI & 523 & 523 & 0 & 0.52 \\
\hline Palisades & PWR & Grand Rapids & MI & 585 & 585 & 0 & 0.59 \\
\hline Monticello & BWR & Saint Cloud & $\mathrm{MN}$ & 426 & 426 & 0 & 0.43 \\
\hline Praine Island & PWR & Minnespolis & $\mathrm{MN}$ & 866 & 866 & 0 & 0.87 \\
\hline Davis-Besse & PWR & Toledo & $\mathrm{OH}$ & 505 & 505 & 0 & 0.51 \\
\hline Perry: & BWR & Cleveland & $\mathrm{OH}$ & 452 & 452 & 0 & 0.45 \\
\hline Kewaunee & PWR & Milwaukee & WI & 451 & 451 & 0 & 0.45 \\
\hline Lacrosse & BWR & La Crosse & WI & 38 & 0 & 38 & 0.00 \\
\hline Point Beach & PWR & Milwaukee & WI & 876 & 876 & 0 & 0.88 \\
\hline Regeion rotal & & & & 14.682 & 14.511 & 171 & 15 \\
\hline
\end{tabular}


Table A.1.1-4. Region 4 SNF \& HLW inventory.

\begin{tabular}{|c|c|c|c|c|c|c|c|}
\hline Site & Fuel type & $\begin{array}{l}\text { Site locacion } \\
\text { near-by city }\end{array}$ & State & $\begin{array}{l}\text { Total } \\
\text { MTHM }\end{array}$ & $\begin{array}{l}\text { MTHM in } \\
\text { Zircaloy }\end{array}$ & $\begin{array}{c}\text { MTHM in } \\
\text { stainless steel }\end{array}$ & $\begin{array}{c}\text { MTHM in } \\
\text { juvenile } \\
\text { fallure }\end{array}$ \\
\hline Arkansas Nuclear One & PWR & Little Rock & AR & 1,109 & -1.109 & 0 & 1.11 \\
\hline Wolf Creek & PWR & Wichita & KS & 630 & 630 & 0 & 0.63 \\
\hline River Bend & BWR & Baton Rouge & LA & 531 & 531 & 0 & 0.53 \\
\hline Waterford & PWR & New Orleans & LA & 500 & 500 & 0 & 0.50 \\
\hline Callaway & PWR & Columbia & MO & 702 & 702 & 0 & 0.70 \\
\hline Grand Gulf & BWR & Vicksburg & MS & 856 & 856 & 0 & 0.86 \\
\hline Cooper & BWR & Omaha & NE & 452 & 452 & 0 & 0.45 \\
\hline Fort Calhoun & PWR & Omaha & NE & 379 & 379 & 0 & 0.38 \\
\hline Comanche Peak & PWR & Dallas & $\mathbf{T X}$ & 998 & 998 & 0 & 1.00 \\
\hline South Texas & PWR & Victoria & TX & 1,012 & 1.012 & 0 & 1.01 \\
\hline Region total & & & & 7,170 & 7.170 & 0 & 7 \\
\hline
\end{tabular}

Table A.1.1-5. Region 5 SNF and HLW inventory.

\begin{tabular}{|c|c|c|c|c|c|c|c|}
\hline Site & Fuel type & $\begin{array}{l}\text { Site location } \\
\text { near-by city }\end{array}$ & State & $\begin{array}{l}\text { Total } \\
\text { MTHM }\end{array}$ & $\begin{array}{l}\text { MTHM in } \\
\text { Zircaloy }\end{array}$ & $\begin{array}{c}\text { MTHM in } \\
\text { stuinless steel }\end{array}$ & $\begin{array}{c}\text { MTHM in } \\
\text { juvenile } \\
\text { failure }\end{array}$ \\
\hline Palo Verde & PWR & Phoenix & $A Z$ & 1.674 & 1.674 & 0 & 1.67 \\
\hline Dizblo Canyon & PWR & Santa Maria & CA & 1,126 & 1.126 & 0 & 1.13 \\
\hline Humboldt Bay & BWR & Eureka & CA. & 29 & 29 & 0 & 0.03 \\
\hline Rancho Seco & PWR & Sacramento & CA & 228 & 228 & 0 & 0.23 \\
\hline San Onofre & PWR & San Diego & $\mathrm{CA}$ & 1.423 & 1,279 & 144 & 1.28 \\
\hline Trojan & PWR & Portland & OR & 359 & 359 & 0 & 0.36 \\
\hline Washington Nuclear & BWR & Richland (Hanford) & WA & 581 & 581 & 0 & 0.58 \\
\hline Hanford & DOE SNF & Richland (Hanford) & WA & $*$ & & & \\
\hline Hanford & DOE HLW & Richland (Hanford) & WA & $*$ & & & \\
\hline Idaho National Engr Laboratory & DOE SNF & Idaho Falls & $\mathbb{D}$ & $*$ & & & \\
\hline For St Vrain & DOE SNF & Fon Collins & $\mathrm{CO}$ & - & & & \\
\hline Region toul & & & & 5.420 & 5.276 & 144 & 5 \\
\hline
\end{tabular}

- See Table $1-1$ for quantity of DOE-SNF and DOE-HLW.

The original source of the data used in Tables A.1.2-1, A.1.2-2, A.1.2-3, A.1.2-4. and A.1.2-5 are described below:

- Columns 1 and 2 are the same as in Tables A.1.1-1, A.1.1-2, A.1.1-3, A.1.1-4, and A.1.1-5.

- The curies Am-Pu in columns 3 and 4 were obtained by multiplying the mass from Tables A.1.1-1, A.1.1-2, A.1.1-3, A.1.1-4, and A.1.1-5 by 1040 curies per MTHM. This factor was determined by summing the curies of Am-243, Pu-239, Pu-240 and Pu-242 from Table A.2.1-8 of YM EIS Appendix $A$ and converting the curies of Am-Pu per fuel assembly to curies per fuel MTHM. This calculation assumes that all of the stainless steel clad SNF and all of the SNF with juvenile Zircaloy failure would be released during the 10,000-year period.

- The curies of Am-Pu in DOE SNF was obrained for the same four radionuclides from the information given for categories $1,4,5,6,8$, and 11 in YM EIS Appendix A Table A.2.2-4 for each DOE site. Calculations showed the amount of Am-Pu in the DOE SNF at Hanford to be 557,000 curies, at INEEL to be 114,000 curies, at SRS to be 15,000 curies. DOE-SNF curie content at Fort St. Vrain was not provided in YM EIS Appendix A Table A.2.2-4 and was estimated to be 4,300. This estimate assumed that the Fort St. Vrain SNF had the average Am-Pu content of other DOE SNF. Mass of Fort St. Vrain DOE SNF was obtained from YM EIS Apper.dix A. Table A.2.2-2. This 
calculation assumed that all of the Am-Pu in the surrogate DOE-SNF would be released during the 10,000-year period. These values are presented in column 5.

- The curies of Am-Pu released from DOE HIW were based on assumptions of the amount of HLW that would be released during the 10,000-year period: $1 \%$ of Hanford HLW, $8 \%$ of SRS HLW, and $2 \%$ of West Valley HLW. These estimates were based on preliminary flux calculations made by Pacific Northwest National Laboratory that reflected the expected storage conditions and the environmental conditions of the sites.

- Using the above estimates of fraction of HLW dissolved at each site and the Am-Pu content for the four radionuclides from YM EIS Appendix A Tables A.2.2-3, A.2.2-5, and A.2.2-6 for Hanford, SRS, and WVDP, respectively the curies of Am-Pu released were determined. The calculated values are: Hanford 69, SRS 10.400, WVDP 75. These values are presented in column 6 of the attached tables.

Table A.1.2-1. Region $1 \mathrm{Am}-\mathrm{Pu}$ curies released in 10,000 years.

\begin{tabular}{|c|c|c|c|c|c|}
\hline Site & $\begin{array}{l}\text { Fuel } \\
\text { type }\end{array}$ & $\begin{array}{l}\mathrm{Ci} \mathrm{Am} \text { and } \mathrm{Pu} \text { in } \\
\text { juvenile } \mathrm{C} \mathrm{SNF}\end{array}$ & $\begin{array}{l}\mathrm{Ci} A m \text { and } \mathrm{Pu} \\
\text { in SS CSNF }\end{array}$ & $\begin{array}{l}\mathrm{Ci} \text { Am and } \mathrm{Pu} \\
\text { in DOE SNF }\end{array}$ & $\begin{array}{l}\mathrm{Ci} A m \text { and } \mathrm{Pu} \\
\text { in DOE HLW }\end{array}$ \\
\hline Haddam Neck & PWR & 62 & 374,400 & & \\
\hline Millstone & PWR & 839 & 0 & & \\
\hline Millstone & BWR & 776 & 0 & & \\
\hline Salem/Hope Creek & PWR & 582 & 0 & & \\
\hline Salem/Hope Creek & BWR & 945 & 0 & & \\
\hline Pilgrim & BWR & 453 & 0 & & \\
\hline Seabrook & PWR & 442 & 0 & & \\
\hline Maine Yankee & PWR & 557 & 0 & & \\
\hline Calvert Cliffs & PWR & 1188 & 0 & & \\
\hline Oyster Creek & BWR & 601 & 0 & & \\
\hline Fizpatrick/Nine Mile Point & BWR & 1558 & 0 & & \\
\hline Ginna & PWR & 481 & 0 & & \\
\hline Indian Point & PWR & 1179 & 0 & & \\
\hline Indian Point 1 & BWR & 0 & 26,660 & & \\
\hline Yankee-Rowe & PWR & 110 & 21,840 & & \\
\hline Beaver Valley & PWR & 1059 & 0 & & \\
\hline Limerick & BWR & 983 & 0 . & & \\
\hline Peach Bottom & BWR & 1336 & 0 & & \\
\hline Susquehanna & BWR & 1097 & 0 & & \\
\hline $\begin{array}{l}\text { Three Mile Island } \\
\text { Vermont Yankee }\end{array}$ & $\begin{array}{l}\text { PWR } \\
\text { BWR }\end{array}$ & $\begin{array}{l}570 \\
524\end{array}$ & $\begin{array}{l}0 \\
0\end{array}$ & & \\
\hline $\begin{array}{l}\text { West Valley Demo Project } \\
\text { Region total }\end{array}$ & DOE HLW & $F 15,344$ & 422,900 & Total $\mathrm{CI}$ & $\begin{array}{r}74.6 \\
438,318\end{array}$ \\
\hline
\end{tabular}


Table A.1.2.2. Region $2 \mathrm{Am}$-Pu curies released in 10.000 years.

\begin{tabular}{|c|c|c|c|c|c|}
\hline Site & $\begin{array}{l}\text { Fuel } \\
\text { type }\end{array}$ & $\begin{array}{l}\mathrm{Ci} \mathrm{Am} \text { and } \mathrm{Pu} \text { in } \\
\text { juvenile } \mathrm{CSNF}\end{array}$ & $\begin{array}{l}\mathrm{Ci} \mathrm{Am} \text { and } \mathrm{Pu} \\
\text { in SSCSNF }\end{array}$ & $\begin{array}{l}\mathrm{Ci} \mathrm{Am} \text { and } \mathrm{Pu} \\
\text { in DOE SNF }\end{array}$ & $\begin{array}{l}\mathrm{Ci} \mathrm{Am} \text { and } \mathrm{Pu} \\
\text { in DOE HLW }\end{array}$ \\
\hline Browns Ferry & BWR & 1661 & 0 & & \\
\hline Farley & PWR & 1220 & $0^{\circ}$ & - & \\
\hline Crystal River & PWR & 532 & 0 & & \\
\hline St. Lucie & PWR & 1061 & 0 & & \\
\hline Turkey Point & PWR & 1117 & 0 & $\cdot$ & \\
\hline Hatch & BWR & 1244 & 0 & & \\
\hline Vogtle & PWR & 1124 & 0 & & \\
\hline Brunswick & PWR & 142 & 0 & & \\
\hline Brunswick & BWR & 653 & 0 & & \\
\hline Catawba & PWR & 1194 & 0 & & \\
\hline Harris & PWR & 518 & 0 & & \\
\hline Harris & BWR & 217 & 0 & & \\
\hline McGuire , & PWR & 1496 & 0 & & \\
\hline Oconee & PWR & 1940 & 0 & & \\
\hline Robinson & PWR & 399 & 0 & & \\
\hline Summer & PWR & 547 & 0 & & \\
\hline Sequoyah & PWR & 1064 & 0 & & \\
\hline Watts Bar & PWR & 261 & 0 & & \\
\hline North Anna & PWR & 1231 & 0 & & \\
\hline Surry & PWR & 1242 & 0 & & \\
\hline Savannah River Site & DOE-SNF & & & 15,000 & \\
\hline Savannah River Site & DOE-HLW & & & & 10.400 \\
\hline Region total & & 18,864 & 0 & $\begin{array}{l}15,000 \\
\text { Total } \mathrm{Ci}\end{array}$ & $\begin{array}{l}10,400 \\
44,264\end{array}$ \\
\hline
\end{tabular}

Table A.1.2-3. Region $3 \mathrm{Am}-\mathrm{Pu}$ curies released in 10.000 years.

\begin{tabular}{|c|c|c|c|c|c|}
\hline Site & $\begin{array}{l}\text { Fuel } \\
\text { type }\end{array}$ & $\begin{array}{l}\mathrm{Ci} \mathrm{Am} \text { and } \mathrm{Pu} \text { in } \\
\text { juvenile } \mathrm{C} S \mathrm{NF}\end{array}$ & $\begin{array}{l}\mathrm{Ci} \mathrm{Am} \text { and } \mathrm{Pu} \\
\text { in SS CSNF }\end{array}$ & $\begin{array}{l}\mathrm{Ci} \mathrm{Am} \text { and } \mathrm{Pu} \\
\text { in DOE SNF }\end{array}$ & $\begin{array}{l}\mathrm{Ci} A m \text { and } \mathrm{Pu} \\
\text { in DOE HLW }\end{array}$ \\
\hline Duane Arnold & BWR & 401 & 0 & & \\
\hline Braidwood & PWR & 1070 & 0 & & \\
\hline Byron & PWR & 1110 & 0 & & \\
\hline Clinton & BWR & 411 & 0 & & \\
\hline Dresden/Morris & BWR & $1731^{\circ}$ & 0 & & \\
\hline Dresden/Morris & PWR & 0 & 138.320 & & \\
\hline Lasalle County & BWR & 819 & 0 & & \\
\hline Quad Cities & BWR & 1098 & 0 & & \\
\hline Zion & PWR & 1094 & 0 & & \\
\hline Big Rock Point & BWR & 50 & 0 & & \\
\hline Cook & PWR & 1490 & 0 & & \\
\hline Enrico Fermi & BWR & 450 & 0 & & \\
\hline Palisades & PWR & 609 & 0 & & \\
\hline Monticello & BWR & 367 & 0 & & \\
\hline Prairie Island & PWR & 901 & 0 & & \\
\hline Davis-Besse & PWR & 526 & 0 & & \\
\hline Perry & BWR & 389 & 0 & & \\
\hline Kewaunee & PWR & 469 & 0 & & \\
\hline Lacrosse & BWR & 0 & 32,653 & & \\
\hline Point Beach & PWR & 911 & 0 & & \\
\hline Region total & & 2895 & 170,973 & $\begin{array}{r}0 \\
\text { Total Ci }\end{array}$ & $\begin{array}{c}0 \\
0 \\
184,868\end{array}$ \\
\hline
\end{tabular}


Table A.1.2-4. Region 4 Am-Pu curies released in 10,000 years.

\begin{tabular}{|c|c|c|c|c|c|}
\hline Site & $\begin{array}{l}\text { Fuel } \\
\text { type }\end{array}$ & $\begin{array}{l}\mathrm{Ci} A m \text { and } \mathrm{Pu} \text { in } \\
\text { juvenile } \mathrm{C} \mathrm{SNF}\end{array}$ & $\begin{array}{l}\mathrm{Ci} \mathrm{Am} \text { and } \mathrm{Pu} \\
\text { in SS CSNF }\end{array}$ & $\begin{array}{l}\mathrm{Ci} \mathrm{Am} \text { and } \mathrm{Pu} \\
\text { in DOE SNF }\end{array}$ & $\begin{array}{l}\mathrm{Ci} A m \text { and } \mathrm{Pu} \\
\text { in } \mathrm{DOE} \mathrm{HLW}\end{array}$ \\
\hline Arkansas Nuclear One & PWR & 1154 & 0 & & \\
\hline Wolf Creek & PWR & 655 & 0 & - & \\
\hline River Bend & BWR & 457 & 0 & & \\
\hline Waterford & PWR & 520 & 0 & & \\
\hline Callaway & PWR & 730 & 0 & . & . \\
\hline Grand Gulf & BWR & 736 & 0 & & \\
\hline Cooper & BWR & 389 & 0 & & \\
\hline Fort Calhoun & PWR & 394 & 0 & & \\
\hline Comanche Peak & PWR & 1037 & 0 & & \\
\hline South Texas & PWR & 1053 & 0 & & \\
\hline Region total & & 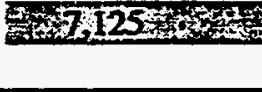 & 407 & 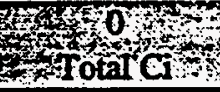 & $\begin{array}{l}0 \\
\times \\
7,125\end{array}$ \\
\hline
\end{tabular}

Table A.1.2-5. Region $5 \mathrm{Am}-\mathrm{Pu}$ curies released in 10.000 years.

\begin{tabular}{|c|c|c|c|c|c|}
\hline Site & $\begin{array}{l}\text { Fuel } \\
\text { type }\end{array}$ & $\begin{array}{l}\mathrm{Ci} \mathrm{Am} \text { and } \mathrm{Pu} \text { in } \\
\text { juvenile } \mathrm{C} \mathrm{SNF}\end{array}$ & $\begin{array}{l}\mathrm{Ci} \mathrm{Am} \text { and } \mathrm{Pu} \\
\text { in SS CSNF }\end{array}$ & $\begin{array}{l}\mathrm{Ci} \mathrm{Am} \text { and } \mathrm{Pu} \\
\text { in DOE SNF }\end{array}$ & $\begin{array}{l}\text { Ci Am and Pu } \\
\text { in DOE HLW }\end{array}$ \\
\hline Palo Verde & PWR & 1741 & 0 & & \\
\hline Diablo Canyon & PWR & 1172 & 0 & & \\
\hline Humboldt Bay & BWR & 25 & 0 & & \\
\hline Rancho Seco & PWR & 238 & 0 & & \\
\hline San Onofre & PWR & 1330 & 149,760 & & \\
\hline Trojan & PWR & 373 & 0 & & \\
\hline Washington Nuclear & BWR & 499 & 0 & & \\
\hline Hanford & DOE SNF & & & 557,000 & \\
\hline Hanford & DOE HLW & & & & 69 \\
\hline $\begin{array}{l}\text { Idaho National Engr } \\
\text { Laboratory }\end{array}$ & DOE SNF & & & 114,000 & \\
\hline Fort St Vrain & DOE SNF & & & 4,320 & \\
\hline Region total & & $25,377,0$ & 149,760 & $\begin{array}{l}675,320 \\
\text { Total Ci }\end{array}$ & 830,526 \\
\hline
\end{tabular}

The source of the data in Tables A.1.3-1, A.1.3-2, A.1.3-3, A.1.3-4, and A.1.3-5 are described below.

- Columns 1 and 2 are same as discussed previously.

- The methodology for determining concrete life for commercial SNF storage is described in Reference 8 and actual calculated values are described in Reference 7. Reference 7 documented the preparation of Figure A.1-1 which divided the United States into five relatively constant concretefailure zones. 


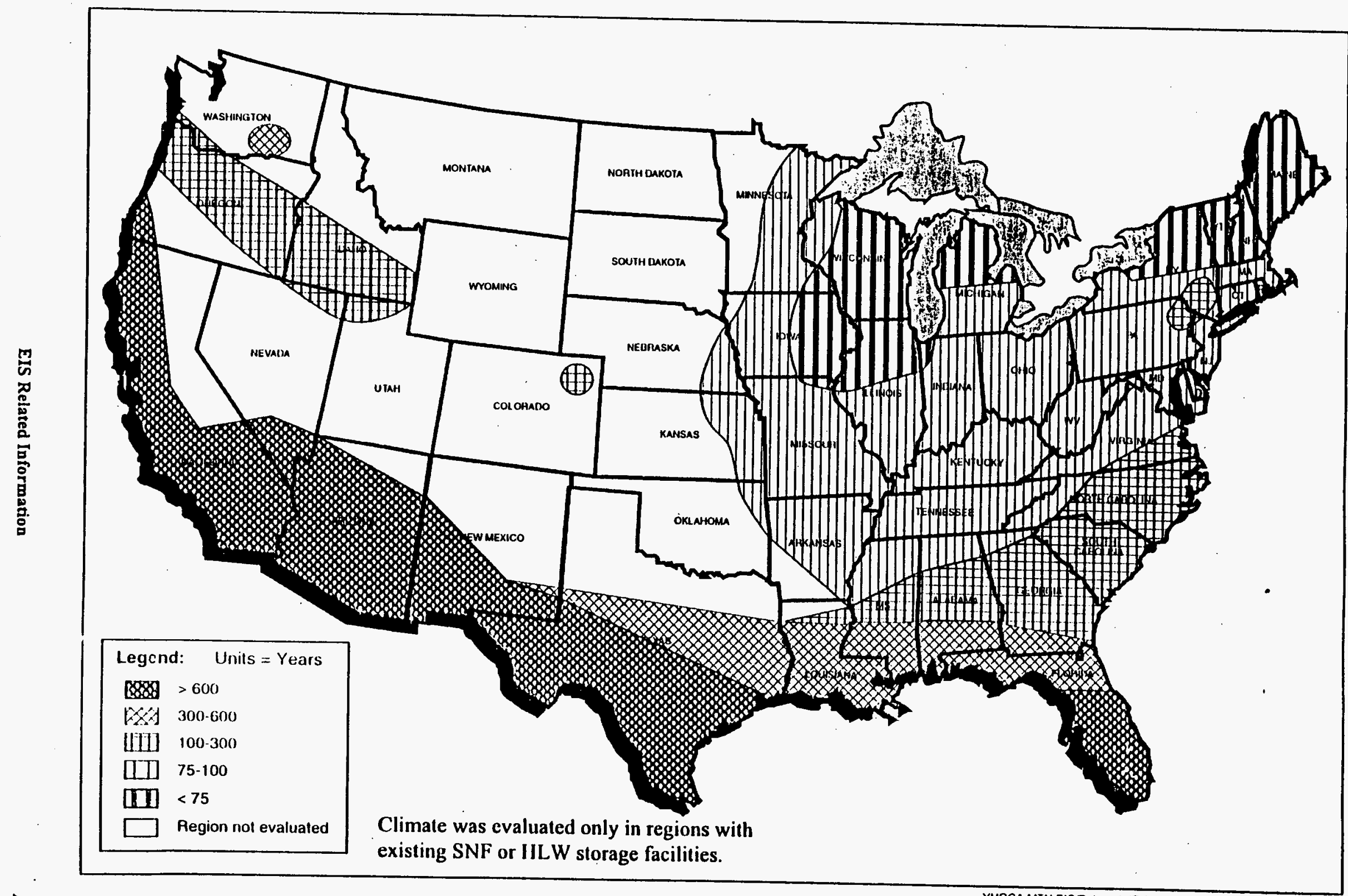


These failure zones were used to determine the failure times used in the regional analysis. Failure times were selected for use on Tables A.1.3-1, A.1.3-2, A.1.3-3, A.1.3-4, and A.1.3-5 from values near the midrange of the failure times. Failure times for each zones used are listed below.

\begin{tabular}{cc}
\hline Failure time range (yrs) & Failure time used (yrs.) \\
\hline$<75$ & 67 \\
$75-100$ & 87 \\
$100-300$ & 200 \\
$300-600$ & 450 \\
$>600$ & 3550 \\
\hline
\end{tabular}

- The methodology used to identify precipitation regions is described in Reference 7. That reference identified precipitation regions based upon precipitation rates as shown in Figure A.1-2. Precipitation rates, shown in the fourth column of Tables A.1.3-1, A.1.3-2, A.1.3-3, A.1.3-4, and A.1.3-5, were used for each site within the region. The rate was valued near the mid range of the precipitation range. Precipitation rates used in the following tables were as follows:

\begin{tabular}{cc}
\hline Precipitation range (in/yr) & Rate. in/yr \\
\hline$<30$ & 10.5 \\
$30-35$ & 32.5 \\
$35-40$ & 37.5 \\
$40-45$ & 42.5 \\
$>45$ & 52.2 \\
\hline
\end{tabular}

The region <30" used the average precipitation rate for the commercial SNF, DOE SNF, and DOE HLW which is $10.5^{\prime \prime} / \mathrm{yr}$. The $>45^{\prime}$ region used a precipitation rate of $52.2 " / \mathrm{yr}$ to represent precipitation rates between $45^{\prime \prime} / y r$ and rates larger than $60 " / y r$ along the Gulf Coast in parts of LA, $\mathrm{MS}$, and AL.

- The approach used to obtain data on relative humidity (Columns 5 and 6) is described in Reference 7. This data was not binned by region but site specific data is shown on these tables.

- The seventh column is the percent of days with rain.

- The eighth column is the sum of fraction of days with precipitation and fraction of time with that relative humidity exceeds 85 percent. The data in this eighth column was used to develop the stainless steel corrosion rate. Where relative humidity is greater than 85 percent, the corrosion of this stainless steel tend to behave just as it does with precipitation.

- The precipitation chemistry information shown in columns 9, 10, and 11 of Tables A.1.3-1, A.1.3-2, A.1.3-3, A.1.3-4, and A.1.3-5 were obtained from Figures A.1-3, A.1-4, and A.1-5. The source of the three figures is described in Reference 7 . These three chemistry components of precipitation are the primary environmental parameters that affect waste package, cladding, and SNF and HLW degradation. The chloride and sulfate concentrations (Columns 10 and 11 ) are expressed as weight percent impurity while in the two associated figures they are expressed as molarity. The conversion between the two is straightforward.

- The data in the last column is the mean average temperature for each site. The source of this data is described in Reference 7 . It is a 30-year annual average temperature. 


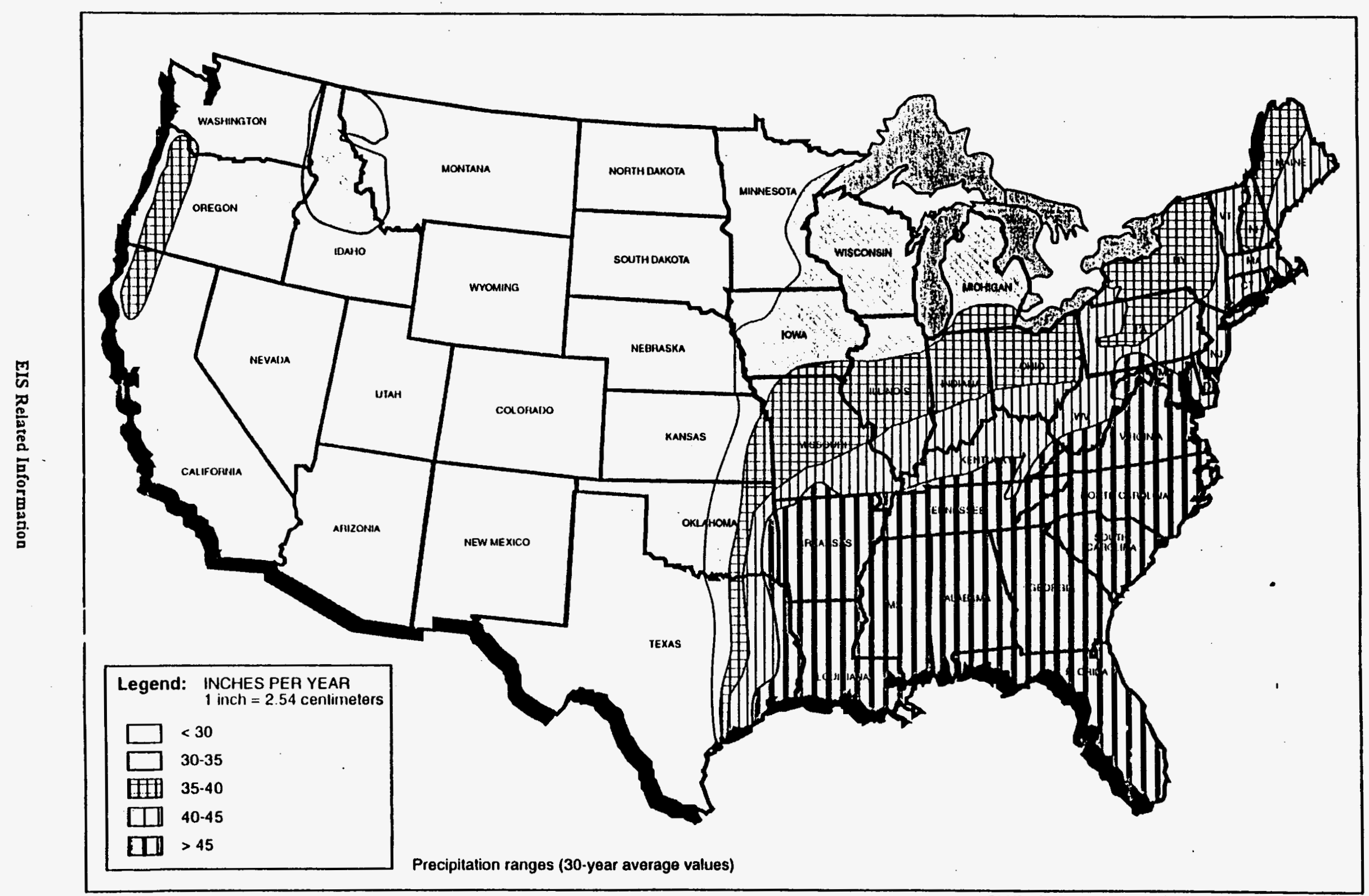




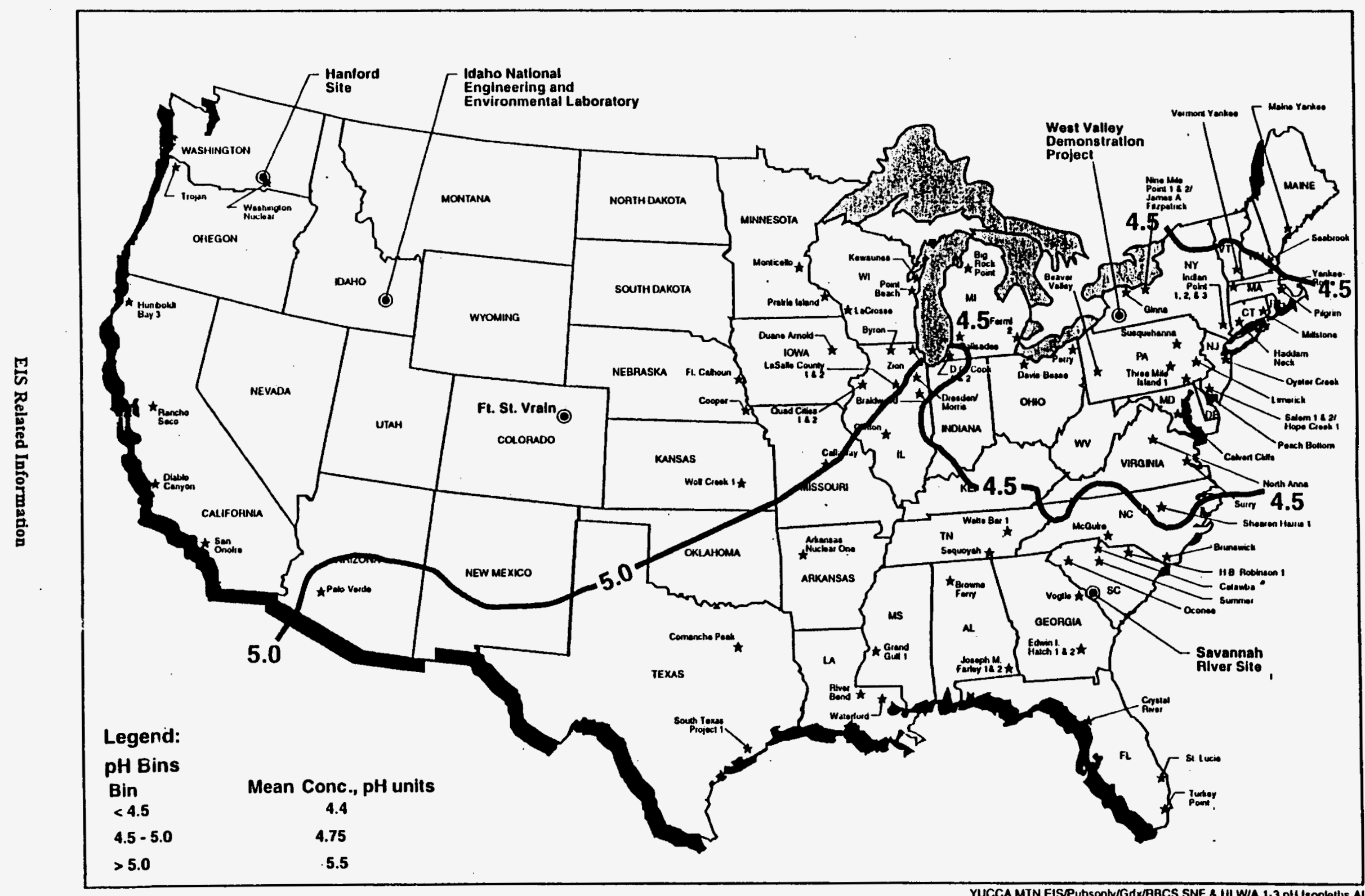

Figure A.1-3. pll isopleths.

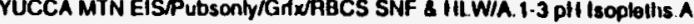




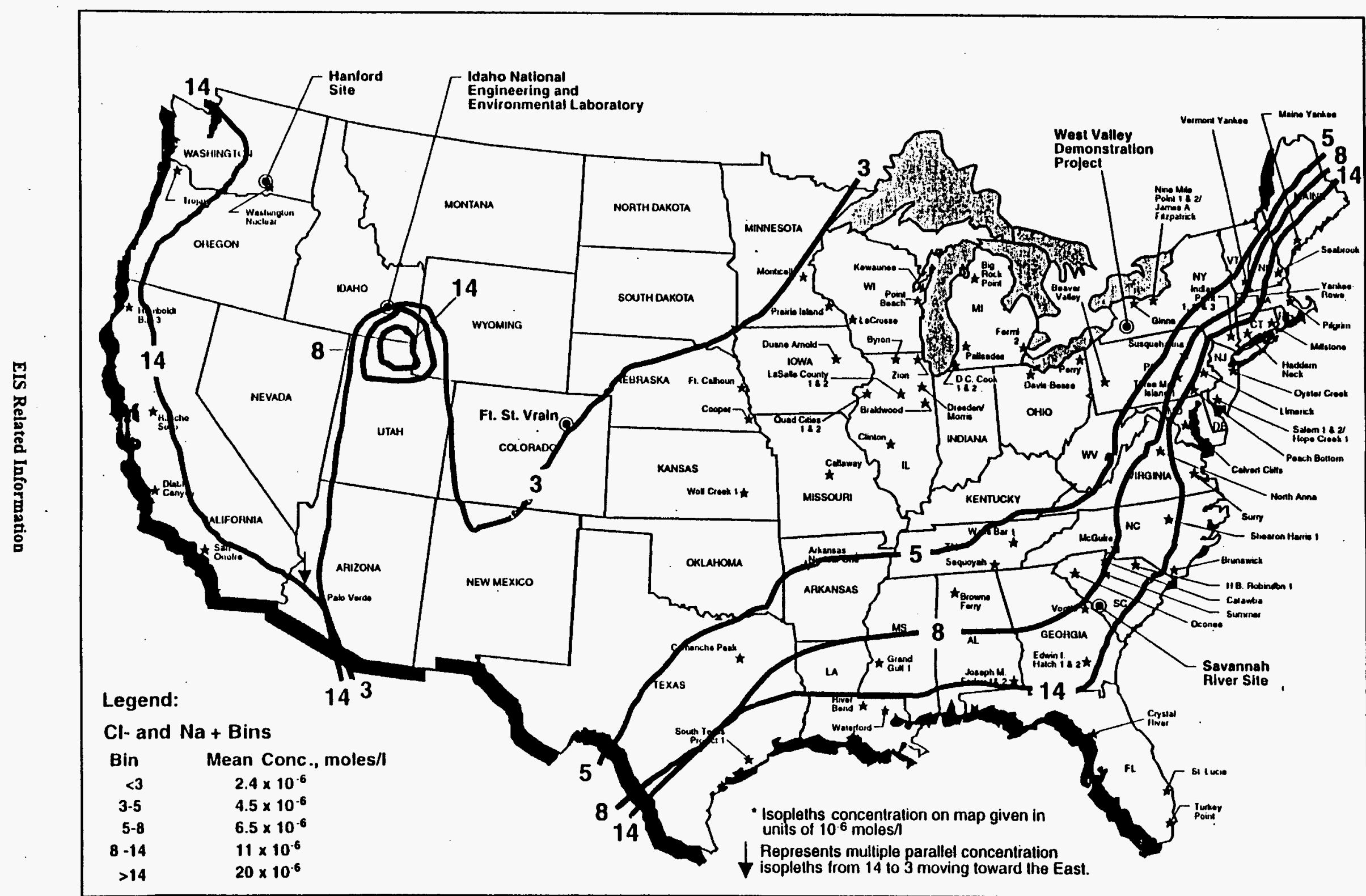

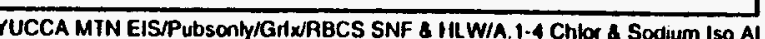




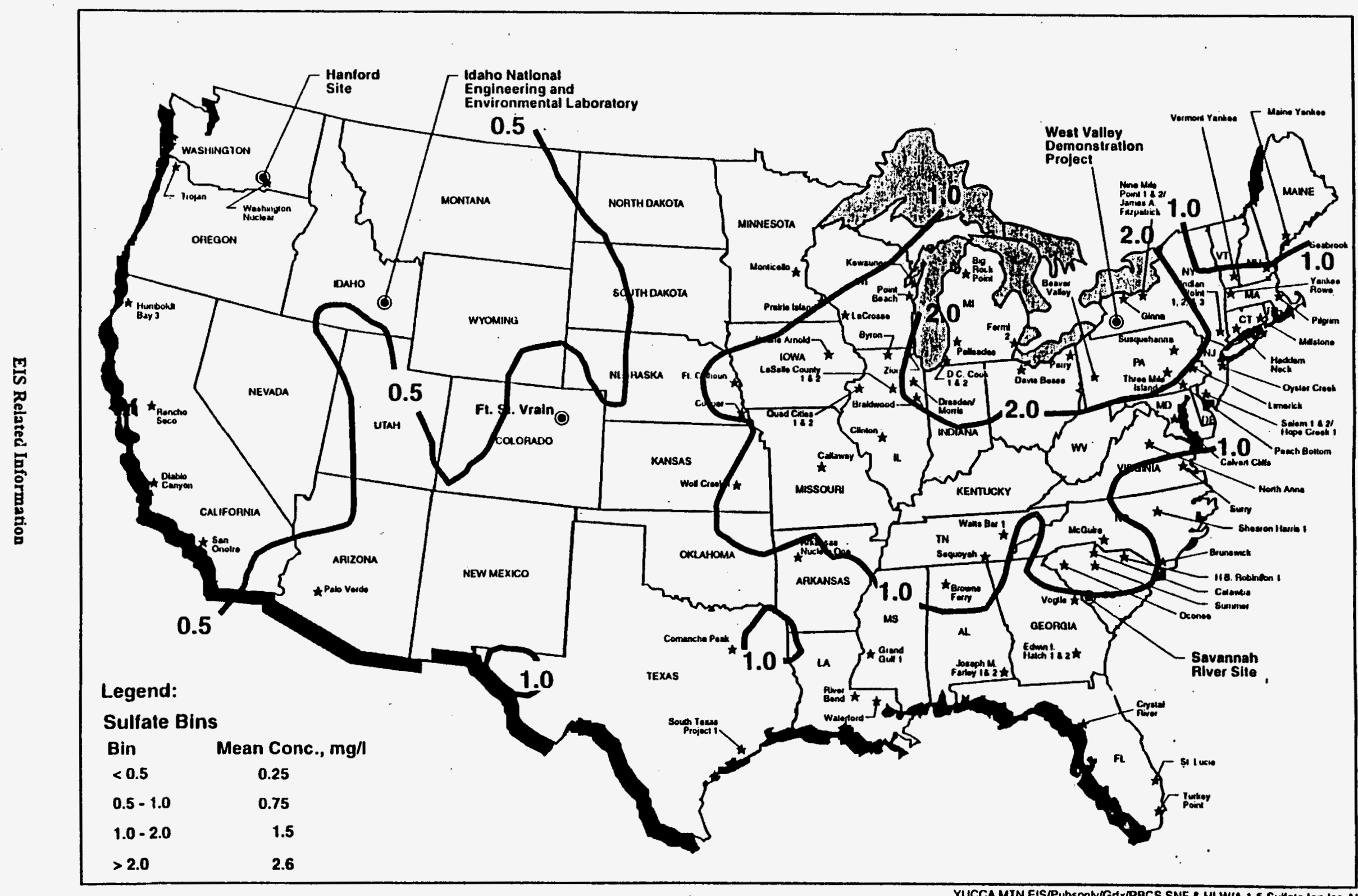

YUCCA MTN EIS/PUbsonIy/GriWRBCS SNF \& HILW/A.1.5 Sultale ton Iso.AI 
I'alole A.1.3-1. Region I environmental parameters.

\begin{tabular}{|c|c|c|c|c|c|c|c|c|c|c|c|}
\hline \multirow[b]{2}{*}{ Site } & \multirow[b]{2}{*}{ Fucl type } & \multirow[b]{2}{*}{$\begin{array}{l}\text { Concrete } \\
\text { life }\end{array}$} & \multirow[b]{2}{*}{$\begin{array}{l}\text { Precipilalion } \\
\text { ralle used. } \\
\text { in/yr }\end{array}$} & \multicolumn{2}{|c|}{ Relative humidity } & \multirow{2}{*}{$\begin{array}{l}\text { Rain-days } \\
\begin{array}{c}\text { Percent of } \\
\text { ycar }\end{array}\end{array}$} & \multirow{2}{*}{$\begin{array}{l}\text { Tolal } \\
\text { Wel diays } \\
\text { \% of year }\end{array}$} & \multicolumn{3}{|c|}{ Precipitallon chemistry dalla } & \multirow[b]{2}{*}{$\begin{array}{l}\text { Averago } \\
\text { temp for } \\
\text { year. "1: }\end{array}$} \\
\hline & & & & $\begin{array}{c}\text { Jime } \\
6 \text { hir/month } \\
R \| 1>85 \%\end{array}$ & $\begin{array}{c}\text { Percent of } \\
\text { year }\end{array}$ & & & pH & $\mathrm{C}$, wi \% & $\begin{array}{l}\mathrm{SO}_{4}= \\
\mathrm{w1} \%\end{array}$ & \\
\hline Ilandalain Neck & PWR & 87 & 42.5 & 0 & 0,0 & 30.1 & 30.1 & 4.4 & 7.1E-05 & 1.5E:-04 & 51.7 \\
\hline Millstone & PWR & 87 & 42.5 & 0 & 0.0 & 30.1 & 30.1 & 4.4 & 7.11E-05 & 1.5E-(1)4 & 51.7 \\
\hline Millstone & BWR & 87 & 42.5 & 0 & 0.0 & 30.1 & 30.1 & 4.4 & 7.1E-05 & I.5E-04 & 51.7 \\
\hline Sillem/l lope Creck & PWR & 87 & 42.5 & 0 & 0.0 & 30.1 & 30.1 & 4.4 & 7.IIR-05 & $1.5 \mathrm{E}-(04$ & 54.2 \\
\hline Sillemv/lope Creck & BWR & 87 & 42.5 & ) & 0.0 & 30.1 & 30.1 & 4.4 & 7.1E-05 & $1.5 \mathrm{E}-(14$ & 54.2 \\
\hline Pilgrim & BWR & 87 & 42.5 & 0 & 0.0 & 30.1 & 30.1 & 4.4 & 7.1E-05 & 7.5E-0.5 & 51.3 \\
\hline Seabrook & PWR & 67 & 32.5 & 6 & 12.5 & 32.9 & 45.4 & 4.75 & 7.1E-05 & I.5E.-04 & 45.4 \\
\hline Maine Yankee & PWR & 67 & 42.5 & 6 & 12.5 & 30.1 & 42.6 & 4.75 & 7.IE-05 & 7.5E-0.5 & 45.4 \\
\hline Calvert Clifis & PWR & 200 & 52.2 & 0 & 0.0 & 29.3 & 29.3 & 4.4 & 7.IE-05 & $7.5 \mathrm{E}-0.5$ & 58.0 \\
\hline Oyster Creck & ISWR & 67 & 42.5 & 8 & 16.7 & 30.1 & 46.8 & 4.4 & $7.113-0.5$ & 1.5L-(0) & 53.0 \\
\hline Fitzpatrick/Nine Mile Point & IHWR & 67 & 37.5 & 4 & 8.3 & 30.7 & 39.0 & 4.4 & 1.6E-05 & 2.6E-04 & 47.4 \\
\hline Ginna & PWR & 67 & 37.5 & 5 & 10.4 & 30.7 & 41.1 & 4.4 & 1.613-05 & 2.6F:-(1)4 & 47.6 \\
\hline Indian Point & PWR & 200 & 42.5 & 0 & 0.0 & 30.1 & 30.1 & 4.4 & 7. IB-(1)5 & 1.5E-()4 & 54.6 \\
\hline Indian Point I & BWR & 200 & 42.5 & () & 0.0 & 30.1 & 30.1 & 4.4 & 7.1E-05 & $1.5 \mathrm{E}-(1) 4$ & 54.6 \\
\hline Yankec-Rowe & PWR & 67 & 37.5 & 5 & 10.4 & 30.7 & 41.1 & 4.4 & $3.9 \mathrm{E}-05$ & $1.55-04$ & 47.4 \\
\hline Heaver Valley & PWR & 87 & 42.5 & 2 & 4.2 & 30.1 & 34.3 & 4.4 & I.6L-0.5 & 2.6E-(1)4 & 50.3 \\
\hline Limerick & BWR & 200 & 42.5 & 1.5 & 3.1 & 30.1 & 33.3 & 4.4 & 7.IE-105 & $1.5 \mathrm{E}-(1) 4$ & 54.3 \\
\hline Peach Boilom & BWWR & 2010 & 42.5 & $\mathbf{0}$ & 0.0 & .30 .1 & 30.1 & 4.4 & 7.11:-0.5 & 1.5E-(1)4 & 54.3 \\
\hline Susquchimmil & BWR & 87 & 42.5 & 2 & 4.2 & 30.1 & 34.3 & 4.4 & 3.91:-0.5 & 2.6E-(24 & 49.1 \\
\hline 'Three Mile Island & PWR & 87 & 42.5 & 0 & 0.0 & 30.1 & 30.1 & 4.4 & $3.91 !-05$ & 2.6F-(04 & 52.9 \\
\hline Vermomi Yankee & BWR & 67 & 42.5 & 5 & 10.4 & 30.1 & 40.6 & 4.4 & $1.61:-05$ & $|.5|:-() 4$ & 47.4 \\
\hline West Valley Demo Projecl & DOE IILW & 67 & 42.5 & .5 & 10.4 & 30.1 & 40.5 & 4.4 & $7.1 \mathrm{E}-05$ & $1.5 \mathrm{~L}-(04$ & 54.6 \\
\hline
\end{tabular}


Table A.1.3-2. Region 2 envirommental parameters.

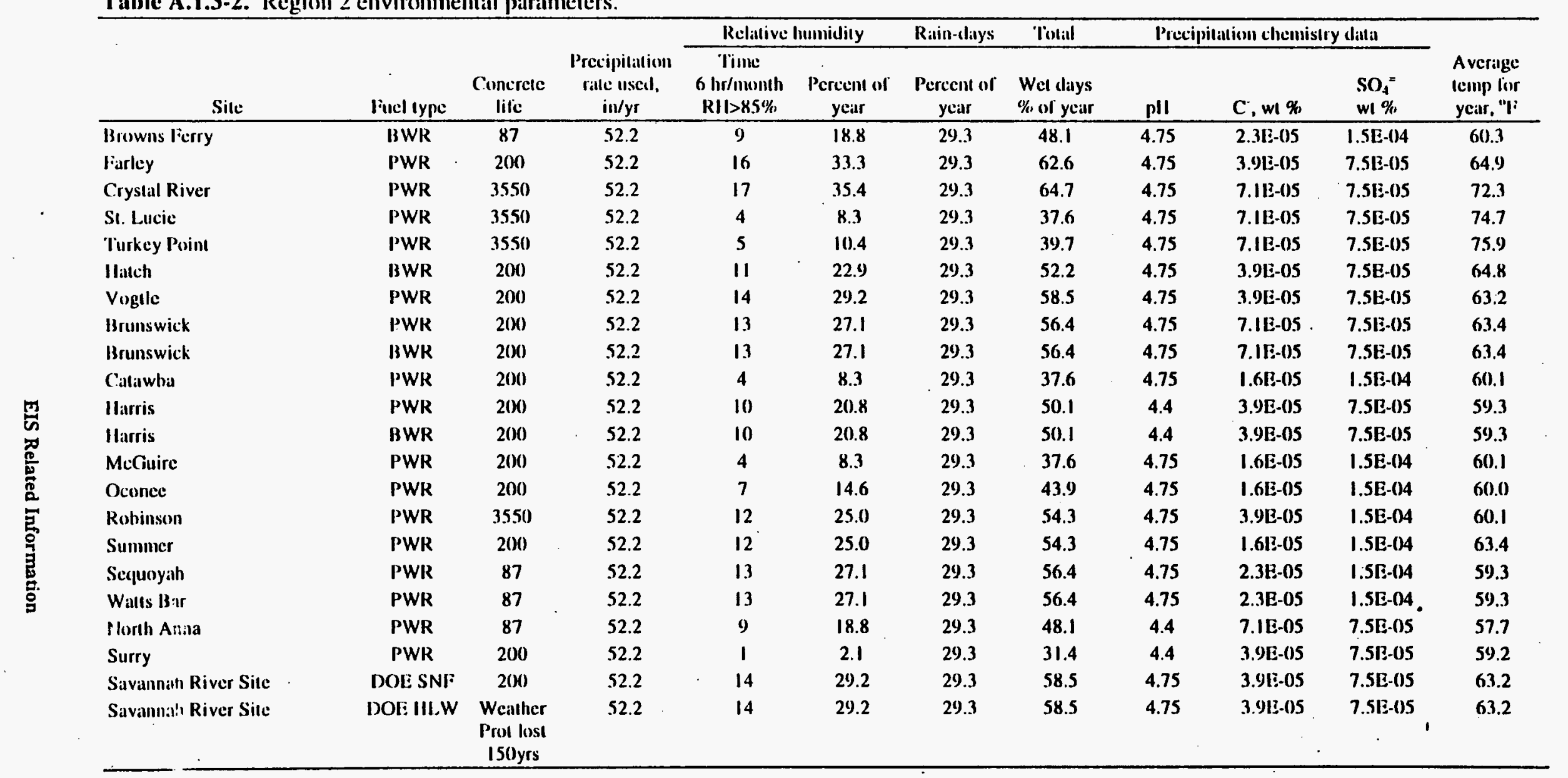


Table A.1.3-3. Region 3 environmental paramelers.

\begin{tabular}{|c|c|c|c|c|c|c|c|c|c|c|c|}
\hline \multirow[b]{2}{*}{ Sitc } & \multirow[b]{2}{*}{ Finel type } & \multirow[b]{2}{*}{$\begin{array}{l}\text { Concrele } \\
\text { life }\end{array}$} & \multirow[b]{2}{*}{$\begin{array}{l}\text { Precipitation } \\
\text { ratce uscd, } \\
\text { in/yr }\end{array}$} & \multicolumn{2}{|c|}{ Relative humidity } & \multirow{2}{*}{$\begin{array}{l}\text { Rain-days } \\
\begin{array}{c}\text { Percenl of } \\
\text { year }\end{array}\end{array}$} & \multirow{2}{*}{$\begin{array}{l}\text { Total } \\
\text { Wot days } \\
\text { \% of year }\end{array}$} & \multicolumn{3}{|c|}{ Precipitation chemistry data } & \multirow[b]{2}{*}{$\begin{array}{l}\text { Average } \\
\text { lemp liur } \\
\text { year, "I: }\end{array}$} \\
\hline & & & & $\begin{array}{c}\text { Time } \\
6 \mathrm{hr} / \mathrm{monih} \\
\mathrm{R} / \mathrm{l}>\mathrm{85} \%\end{array}$ & $\begin{array}{c}\text { Percenl of } \\
\text { year }\end{array}$ & & & pll & $\mathrm{C}, w 1 \%$ & $\begin{array}{l}\mathrm{SO}_{4}= \\
\mathrm{wI} \%\end{array}$ & \\
\hline Duane Armold & BWR & 87 & 32.5 & 2 & 4.2 & 32.9 & 37.0 & 4.4 & I.6E-(05 & 1.5E-(1)4 & 49.9 \\
\hline Braidwood & PWR & 67 & 32.5 & 4 & 8.3 & 32.9 & 41.2 & 4.75 & 1.6E-05 & 2.6F:-04 & 50.7 \\
\hline Byron & P'WR & 87 & 32.5 & 6 & 12.5 & 32.9 & 45.4 & 4.4 & 1.6E-0.5 & $1.513-(04$ & 47.7 \\
\hline Clinton & HWR & 87 & 37.5 & 3 & 6.3 & 30.7 & 36.9 & 4.75 & 1.6Li-05 & 1.5L-04 & 50.7 \\
\hline Dresden/Morris & HWR & 67 & 32.5 & 4 & 8.3 & 32.9 & 41.2 & 4.75 & 1.6L-05 & $2.6 \mathrm{~L}-(1) 4$ & 50.7 \\
\hline Dresden/Murris & P'WR & 67 & 32.5 & 4 & 8.3 & 32.9 & 41.2 & 4.75 & 1.6E-05 & 2.6F-04 & 50.7 \\
\hline Lasalle County & BWR & 67 & 32.5 & 4 & 8.3 & 32.9 & 41.2 & 4.4 & $1.6 \mathrm{E}-05$ & 2.6E-04 & 50.7 \\
\hline Quad Cities & BWR & 67 & 32.5 & 3 & 6.3 & 32.9 & 39.1 & 4.4 & 1.6E-05 & I.5E-(04 & 49.6 \\
\hline Zion & PWR & 67. & 32.5 & 2 & 4.2 & 32.9 & 37.0 & 4.4 & 1.6E--0S & $2.6 E-(1) 4$ & 46.1 \\
\hline Hig Rock Point & BWR & 67 & 32.5 & 4 & 8.3 & 32.9 & 41.2 & 4.4 & $1.6 \mathrm{E}-0.5$ & $2.6 \Gamma-04$ & 47.1 \\
\hline Cook & PWR & 87 & 32.5 & 2 & 4.2 & 32.9 & 37.0 & 4.4 & I.6li-05 & $2.6 \mathrm{IE}-(04$ & 49.5 \\
\hline L̇urico Fermi & IBWR & 67 & 32.5 & 2 & 4.2 & 32.9 & 37.0 & 4.4 & I.6E--05 & $2.6 \Gamma:-04$ & 48.7 \\
\hline Palisades & PWR & 67 & 32.5 & 3.5 & 7.3 & 32.9 & 40.2 & 4.4 & $1.618-0.5$ & $2.61 ?-(04$ & 49.5 \\
\hline Monticello & BWR & 87 & 32.5 & 4 & 8.3 & 32.9 & 41.2 & 4.4 & 1.6E--05 & 7.55:-05 & 41.5 \\
\hline Prairic Island & PWR & 87 & 32.5 & 1 & 2.1 & 32.9 & 35.0 & 4.4 & $1.6 \mathrm{E}-0.5$ & $7.5 E-105$ & 44.9 \\
\hline Davis-Besse & PWR & 87 & 37.5 & 1.5 & 3.1 & 30.7 & 3.3 .8 & 4.4 & $1.613-05$ & $2.65:-(1) 4$ & 48.5 \\
\hline Perry & IIWR & 87 & 37.5 & 1 & 2.1 & 30.7 & 32.8 & 4.4 & $1.6 \mathrm{~L}-0.5$ & 2.6E--1)4 & 49.6 \\
\hline Kewaunce & PWR & 67 & 32.5 & 2 & 4.2 & 32.9 & 37.0 & 4.4 & 1.6E-05 & $1.51:-(1) 4$ & 46.1 \\
\hline Iikcrosst: & IBWR & 87 & 32.5 & 6 & 12.5 & 32.9 & 45.4 & 4.4 & 1.6E:-05 & $1.5 \mathrm{E}-\left(104^{\circ}\right.$ & 46.2 \\
\hline Poitll lleach & PWR & 67 & 32.5 & 2 & 4.2 & 32.9 & 37.0 & 4.4 & $1.618-0.5$ & I.5E-(1)4 & 46.1 \\
\hline
\end{tabular}


Table A.1.3-4. Region 4 environmental paramelers.

\begin{tabular}{|c|c|c|c|c|c|c|c|c|c|c|c|}
\hline \multirow[b]{2}{*}{ Sile } & \multirow[b]{2}{*}{ liuel lype } & \multirow[b]{2}{*}{$\begin{array}{l}\text { Concrele } \\
\text { life }\end{array}$} & \multirow[b]{2}{*}{$\begin{array}{l}\text { Precipitalion } \\
\text { ralte used, } \\
\text { in/yr }\end{array}$} & \multicolumn{2}{|c|}{ Relalive humidity } & \multirow{2}{*}{$\begin{array}{l}\text { Risin-dlays } \\
\begin{array}{c}\text { Percent of } \\
\text { year }\end{array}\end{array}$} & \multirow{2}{*}{$\begin{array}{l}\text { 'Total } \\
\text { Wel days } \\
\text { \% of year }\end{array}$} & \multicolumn{3}{|c|}{ Precipilinlicul chemislry dalla } & \multirow[b]{2}{*}{$\begin{array}{l}\text { Average } \\
\text { temp for } \\
\text { year, "I: }\end{array}$} \\
\hline & & & & $\begin{array}{c}\text { Time } \\
6 \text { hr/month } \\
\text { RHI>85\% }\end{array}$ & $\begin{array}{c}\text { Percent of } \\
\text { year }\end{array}$ & & & pll & $\mathrm{C}:$ wi \% & $\begin{array}{l}\mathrm{SO}_{4}= \\
\text { wi } \%\end{array}$ & \\
\hline Arkinsas Nuclear One & PWR & 200 & 52.2 & 5 & 10.4 & 29.3 & 39.7 & 4.75 & $1.61 \mathrm{i}-0.5$ & $7.51:-0.5$ & 60.6 \\
\hline Woll Creck & PWR & 200 & 32.5 & 0 & 0.0 & 32.9 & 32.9 & 4.4 & $1.61:-05$ & $1.5 \mathrm{E}-(04$ & 56.2 \\
\hline River Bend & BWWR & 4.50 & 52.2 & 16 & 33.3 & 29.3 & 62.6 & 4.75 & 7.1E-(05 & 7.SE-05 & 67.7 \\
\hline Willertiond & PWR & 4.50 & 52.2 & 16 & 33.3 & 29.3 & 62.6 & 4.75 & 7.1E-05 & 7.5E-(05 & 68.1 \\
\hline Callaway & PWR & 87 & 37.5 & 5.5 & 11.5 & 30.7 & 42.1 & 4.4 & I.6E--05 & I.5E-(1)4 & 53.9 \\
\hline Grand Gulf & HWR & 450 & 52.2 & 19 & 39.6 & 29.3 & 68.9 & 4.75 & $3.9 E-05$ & $1.5 \mathrm{E}-(1) 4$ & $64.2^{\circ}$ \\
\hline Cooper & BWR & 87 & 32.5 & 2 & 4.2 & 32.9 & 37.0 & 4.4 & 1.6E-(05 & $1.5 \mathrm{E}-(1) 4$ & 50.7 \\
\hline Fort Calhoun & PWR & 87 & 32.5 & 2 & 4.2 & 32.9 & 37.0 & 4.4 & 1.6E-(05 & $1.5 \mathrm{E}-(1) 4$ & 50.7 \\
\hline Comanche P'alk & PWR & 450 & 32.5 & 2 & 4.2 & 32.9 & 37.0 & 4.75 & 2.3L:-0.5 & $7.5 E-0.5$ & 6.5 .4 \\
\hline South Texas & PWR & 3550 & 42.5 & 19 & 39.6 & 30.1 & 69.7 & 4.75 & 7.1E-05 & $7.5 \mathrm{E}-1.5$ & 69.9 \\
\hline
\end{tabular}

Table A.1.3-5. Region 5 environmental parameters.

\begin{tabular}{|c|c|c|c|c|c|c|c|c|c|c|c|}
\hline \multirow[b]{2}{*}{ Sile } & \multirow[b]{2}{*}{ Fìcl type } & \multirow[b]{2}{*}{ Concrete life } & \multirow[b]{2}{*}{$\begin{array}{l}\text { Precipitation } \\
\text { ritle used, } \\
\text { in/yr }\end{array}$} & \multicolumn{2}{|c|}{ Relative humidily } & \multirow{2}{*}{$\begin{array}{l}\text { Rain-dlays } \\
\begin{array}{c}\text { Percent of } \\
\text { year }\end{array}\end{array}$} & \multirow{2}{*}{$\begin{array}{l}\text { Total } \\
\text { Wel days } \\
\% \text { of year }\end{array}$} & \multicolumn{3}{|c|}{ Precipitalion cluemislry dala } & \multirow[b]{2}{*}{$\begin{array}{l}\text { Average } \\
\text { temp lor } \\
\text { year, "I } \\
\end{array}$} \\
\hline & & & & $\begin{array}{c}\text { Tiume } \\
6 \mathrm{hr} / \mathrm{monh} \\
\text { RII>85\% }\end{array}$ & $\begin{array}{c}\text { Percent of } \\
\text { year }\end{array}$ & & & $\cdot \mathbf{p H}$ & $\mathrm{C}: \mathrm{w} \%$ & $\begin{array}{l}\mathrm{SO}_{4}= \\
\mathrm{w} \%\end{array}$ & \\
\hline Pallo Verde & PWR & 3550 & 10.5 & 0 & 0.0 & 23.6 & 23.6 & 4.75 & I.6li-0.5 & 7.5F:-05 & 72.6 \\
\hline Diahlo Canyon & PWR & 3.550 & 10.5 & 17 & 35.4 & 23.6 & 59.0 & 4.4 & 7.IE-0.5 & $2.5 \mathrm{E}-0.5$ & 57.3 \\
\hline Iluniboldt Bay & BWR & 3550 & 37.5 & 6 & 12.5 & 30.7 & 43.2 & 4.4 & 7.1E.05 & $2.513-05$ & 52.7 \\
\hline Rancho Seco & PWR & 3550 & 10.5 & 6 & 12.5 & 23.6 & 36.1 & 4.4 & 7 IE-05 & $2.513-05$ & 60.6 \\
\hline Sin Onvire & PWR & 35.50 & 10.5 & 0 & 0.0 & 23.6 & 23.6 & 4.4 & 7.1E-0S & $2.513-0.5$ & 64.2 \\
\hline Trojann & IPWR & 200 & 37.5 & 10 & 20.8 & 30.7 & 51.5 & 5.5 & 7.1E.05 & $2.513-0.5$ & 53.7 \\
\hline Washingitor Nuclcar & BWR & 450 & 10.5 & 0 & 0.0 & 23.6 & 23.6 & 5.5 & $8.56-106$ & $2.5 F-10.5$ & 5.3 .3 \\
\hline Ilanlord & DOL: SNF & $\begin{array}{l}\text { Wealher Prot } \\
\text { losi 1 50yrs }\end{array}$ & 10.5 & 0 & 0.0 & 23.6 & 23.6 & 5.5 & 8.5E-(06 & 2.5E -105 & 53.3 \\
\hline Ilanford & DOE IILW & $\begin{array}{l}\text { Wealher Prol } \\
\text { lost 150yrs }\end{array}$ & 10.5 & $\mathbf{0}$ & $0 .()$ & 23.6 & 23.6 & 5.5 & 8.5E-06 & 2.5F.-0.5 & 53.3 \\
\hline $\begin{array}{l}\text { Jdaho National Eagr } \\
\text { l.aboraltory }\end{array}$ & DOE SNF & $\begin{array}{l}\text { Weather Prot } \\
\text { lost ISOyrs }\end{array}$ & 10.5 & $\mathbf{0}$ & 0.0 & 23.6 & 23.6 & 5.5 & 1.6P-05 & 2,5E-0.5 & 50.3 \\
\hline Forl Si Vrain & DOE SNF & $\begin{array}{l}\text { Weather Prot } \\
\text { lost } 1.50 \mathrm{yrs}\end{array}$ & 10.5 & 3 & 6.3 & 23.6 & 29.9 & 4.4 & 8.5E-(06 & 7.513-05 & 51.5 \\
\hline
\end{tabular}


Appendix B

Transport through Groundwater

\section{B.1 Water Flow Through the Vadose Zone}

The information contained in Tables B.2.1-1, B.2.1-2, B.2.1-3, B.2.1-4, and B.2.1-5 was obtained from Reference 11 and is presented here by region.

Table B.2.1-1. Physical data for vadose zone in Region 1.

\begin{tabular}{|c|c|c|c|c|c|c|c|c|}
\hline \multirow[b]{2}{*}{ Region 1} & \multirow[b]{2}{*}{ Site } & \multirow[b]{2}{*}{ Fuel type } & \multicolumn{6}{|c|}{ Vadose zone } \\
\hline & & & $\begin{array}{l}\text { Clay } \\
\text { content. } \\
\text { wt } \%\end{array}$ & $\begin{array}{l}\text { Thickness, } \\
\text { to saturated } \\
\text { zone, } \\
\text { ft }\end{array}$ & $\begin{array}{l}\text { Bulk } \\
\text { density, } \\
\text { g/cm3 }\end{array}$ & $\begin{array}{c}\text { Porosity, } \\
\text { vol } \%\end{array}$ & $\begin{array}{c}\text { Field } \\
\text { capacity. } \\
\text { vol } \%\end{array}$ & $\begin{array}{c}\text { Sat. } \\
\text { hydraulic } \\
\text { conductivity. } \\
\mathrm{cm} / \mathrm{sec}\end{array}$ \\
\hline 1 & Haddam Neck & PWR & 1 & 10 & 1.64 & 38 & 9 & $6.6 \mathrm{E}-03$ \\
\hline 1 & Millstone & PWR \& BWR & 3 & 20 & 1.64 & 38 & 9 & $6.6 \mathrm{E}-03$ \\
\hline 1 & Salem/Hope Creek & PWR \& BWR & 3 & 60 & 1.64 & 38 & 9 & $6.6 \mathrm{E}-03$ \\
\hline 1 & Pilgrim & BWR & 1 & 55 & 1.64 & 38 & 9 & $6.6 \mathrm{E}-03$ \\
\hline 1 & Seabrook & PWR & 10 & 25 & 1.48 & 44.2 & 17.5 & 7.2E-04 \\
\hline 1 & Maine Yankee & PWR & 1 & 12.5 & 1.64 & 38 & 9 & $6.6 \mathrm{E}-03$ \\
\hline 1 & Calvert Cliffs & PWR & 15 & 10 & 1.42 & 46.3 & 27.5 & $2.0 \mathrm{E}-04$ \\
\hline 1 & Oyster Creek & BWR & 3 & 12 & 1.64 & 38 & 9 & $6.6 E-03$ \\
\hline 1 & Fitzpaurick/Nine Mile Point & BWR & 15 & 6 & 1.72 & 46.3 & 27.5 & $2.0 \mathrm{E}-0.4$ \\
\hline 1 & Ginna & PWR & 15 & 25 & 1.42 & 46.3 & 27.5 & $2.0 \mathrm{E}-04$ \\
\hline 1 & Indian Point & PWR \& BWR & 1 & 10 & 1.64 & 38 & 9 & $6.6 E-03$ \\
\hline 1 & Yankee-Rowe & PWR & 6 & 15 & 1.49 & 43.7 & 12 & 1.9E-03 \\
\hline 1 & Beaver Valley & PWR & 10 & 30 & 1.48 & 44.2 & 17.5 & $7.2 \mathrm{E}-04$ \\
\hline 1 & Limerick & BWR & 0 & 40 & 1.65 & 5 & 2.5 & \\
\hline 1 & Peach Botrom & BWR & 3 & 7 & 1.64 & $\checkmark \quad 38$ & 9 & $6.6 \mathrm{E}-03$ \\
\hline 1 & Susquehanna & BWR & 10 & 50 & 1.48 & 4.2 & 17.5 & 7.2E-O4 \\
\hline 1 & Three .Mile Island & PWR & 3 & 10 & 1.64 & 38 & 9 & $6.6 \mathrm{E} \cdot 03$ \\
\hline 1 & Vermont Yankee & BWR & 6 & 10 & 1.49 & 43.7 & 12 & $1.9 \mathrm{E}-03$ \\
\hline 1 & West Valley Demo Project & DOE HLW & 3 & 8 & 1.88 & 35.2 & 9 & $3.9 \mathrm{E}-04$ \\
\hline
\end{tabular}


Table B.2.1-2. Physical data for vadose zone in Region 2 .

\begin{tabular}{|c|c|c|c|c|c|c|c|c|}
\hline \multirow[b]{2}{*}{ Region 2} & \multirow[b]{2}{*}{ Site } & \multirow[b]{2}{*}{ Fuel type } & \multicolumn{6}{|c|}{ Vadose zone } \\
\hline & & & $\begin{array}{c}\text { Clay } \\
\text { content, } \\
\text { w } \%\end{array}$ & $\begin{array}{l}\text { Thickness. } \\
\text { to saturated } \\
\text { zone. } \\
\text { ft }\end{array}$ & $\begin{array}{l}\text { Bulk } \\
\text { density. } \\
\text { g/cm3 }\end{array}$ & $\begin{array}{l}\text { Porosity, } \\
\text { vol } \%\end{array}$ & $\begin{array}{l}\text { rield } \\
\text { capacity, } \\
\text { vol } \%\end{array}$ & $\begin{array}{c}\text { Sat. } \\
\text { hydraulic } \\
\text { conductivity, } \\
\mathrm{cm} / \mathrm{sec}\end{array}$ \\
\hline$?$ & Browns Ferry & BWR & 6 & 10 & 1.50 & 40 & 10 & $2.0 E-04$ \\
\hline$i$ & Faricy & PWR & 3 & 40 & 1.64 & 38 & 9 & $6.6 E-03$ \\
\hline 2 & Crystal River & PWR & 15 & 10 & 1.42 & 46.3 . & 27.5 & 2.0E-OS \\
\hline 2 & St. Lucie & PWR & 10 & 145 & 1.48 & 44.2 & 17.5 & 7.2E-04 \\
\hline 2 & Turkey Point & PWR & 1 & 70 . & 1.64 & 38 & 9 & $6.6 \mathrm{E}-03$ \\
\hline 2 & Hatch & BWR & 6 & 20 & 1.49 & 43.7 & 12 & $1.9 E-03$ \\
\hline 2 & Vogtle & PWR & 6 & 50 & 1.49 & 43.7 & 12 & $1.9 \mathrm{E}-03$ \\
\hline 2 & Brunswick & PWR & 47 & 25 & 1.36 & 48.6 & 42 & $2.6 \mathrm{E}-05$ \\
\hline 2 & Catawba & PWR & 15 & 15 & 1.42 & 46.3 & 27.5 & $2.0 \mathrm{E}-04$ \\
\hline 2 & Harris & PWR \& BWR & 10 & 15 & 1.48 & 44.2 & 17.5 & $7.2 E-04$ \\
\hline 2 & McGuire & PWR & 15 & 20 & 1.42 & 46.3 & 27.5 & $2.0 \mathrm{E}-04$ \\
\hline 2 & Oconee & PWR & 47 & 35 & 1.36 & 48.6 & 42 & $2.6 \mathrm{E}-05$ \\
\hline 2 & Robinson & PWR & 1 & 25 & 1.64 & 38 & 9 & $6.6 \mathrm{E}-03$ \\
\hline 2 & Summer & PWR & 15 & 30 & 1.42 & 46.3 & 27.5 & $2.0 \mathrm{E}-0.4$ \\
\hline 2 & Sequoyah & PWR & 15 & 45 & 1.42 & 46.3 & 27.5 & $2.0 \mathrm{E}-04$ \\
\hline 2 & Watrs Bar & PWR & 47 & 23 & 1.36 & 48.6 & 42 & 2.6E-05 \\
\hline 2 & Norh Anna & PWR & 15 & 10 & 1.42 & 46.3 & 27.5 & 2.0E-04 \\
\hline 2 & Surry & PWR & 15 & 30 & 1.42 & 46.3 & 27.5 & 2.0E-04 \\
\hline 2 & Savannah River Site & DOE SNF & 6 & 50 & 1.60 & 40 & 10 & $1.0 \mathrm{E}-0.4$ \\
\hline 2 & Savannah River Site & DOE HLW & 6 & 50 & 1.60 & 40 & 10 & $1.0 \mathrm{E}-04$ \\
\hline
\end{tabular}

Table B.2.1-3. Physical data for vadose zone in Region 3.

\begin{tabular}{|c|c|c|c|c|c|c|c|c|}
\hline \multirow[b]{2}{*}{ Region 3} & \multirow[b]{2}{*}{ Site } & \multirow[b]{2}{*}{ Fuel type } & \multicolumn{6}{|c|}{ Vadose zone } \\
\hline & & & $\begin{array}{c}\text { Clay } \\
\text { content, } \\
\text { wt \% }\end{array}$ & $\begin{array}{c}\text { Thickness, } \\
\text { to saturated } \\
\text { zone. } \\
\text { ft }\end{array}$ & $\begin{array}{l}\text { Bulk } \\
\text { density, } \\
\text { g/cm3 }\end{array}$ & $\begin{array}{c}\text { Porosity, } \\
\text { vol } \%\end{array}$ & $\begin{array}{c}\text { Field } \\
\text { capacity, } \\
\text { vol } \% c\end{array}$ & $\begin{array}{c}\text { Sat. } \\
\text { hydraulic } \\
\text { conductivity, } \\
\mathrm{cm} / \mathrm{sec}\end{array}$ \\
\hline 3 & Duane Amold & BWR & 1 & 17 & 1.64 & 38 & 9 & $6.6 \mathrm{E}-03$ \\
\hline 3 & Braidwood & PWR & 3 & 13 & 1.64 & 38 & 9 & $6.6 \mathrm{E}-03$ \\
\hline 3 & Byron & PWR & 15 & 6 & 1.42 & 46.3 & 27.5 & 2.0E-04 \\
\hline 3 & Clinton & BWR & 1 & 6 & 1.64 & 38 & 9 & $6.6 \mathrm{E}-03$ \\
\hline 3 & Dresden/Morris & PWR \& BWR & 15 & 4 & 1.42 & 46.3 & 27.5 & $2.0 \mathrm{E}-04$ \\
\hline 3 & Lasalle County & BWR & 15 & 10 & 1.42 & 46.3 & 27.5 & $2.0 \mathrm{E}-04$ \\
\hline 3 & Quad Cities & BWR & 1 & 30 & 1.64 & 38 & 9 & $6.6 \mathrm{E}-03$ \\
\hline 3 & Zion & PWR & 3 & 20 & 1.64 & 38 & 9 & $6.6 \mathrm{E}-03$ \\
\hline 3 & Big Rock Point & BWR & 3 & 8 & 1.64 & 38 & 9 & $6.6 \mathrm{E}-03$ \\
\hline 3 & Cook & PWR & 3 & 15 & 1.64 & 38 & 9 & $6.6 \mathrm{E}-03$ \\
\hline 3 & Enrico Fermi & BWR & 15 & 20 & 1.42 & 46.3 & 27.5 & $2.0 \mathrm{E}-04$ \\
\hline 3 & Palisades & PWR & 6 & 135 & 1.49 & 43.7 & 12 & 1.9E-03 \\
\hline 3 & Monticello & BWR & 3 & 20 & 1.64 & 38 & 9 & $6.6 \mathrm{E}-03$ \\
\hline 3 & Prairie Island & PWR & 1 & 160 & 1.64 & 38 & 9 & $6.6 E-03$ \\
\hline 3 & Davis-Besse & PWR & 47 & 14 & 1.36 & 48.6 & 42 & 2.6E-05 \\
\hline 3 & Perry & BWR & 10 & 28 & 1.48 & 44.2 & 17.5 & 7.2E-04 \\
\hline 3 & Kewaunee & PWR & 3 & 10 & 1.64 & 38 & 9 & $6.6 \mathrm{E}-03$ \\
\hline 3 & Lacrosse & BWR & 1 & 10 & 1.64 & 38 & 9 & $6.6 \mathrm{E}-03$ \\
\hline 3 & Point Beach & PWR & 6 & 54 & 1.49 & 43.7 & 12 & $1.9 \mathrm{E}-03$ \\
\hline
\end{tabular}


Table B.2.1-4. Physical data for vadose zone in Region 4.

\begin{tabular}{|c|c|c|c|c|c|c|c|c|}
\hline \multirow[b]{2}{*}{ Region 1} & \multirow[b]{2}{*}{ Site } & \multirow[b]{2}{*}{ Fuel type } & \multicolumn{6}{|c|}{ Vadose zone } \\
\hline & & & $\begin{array}{c}\text { Clay } \\
\text { content, } \\
\text { wt } \%\end{array}$ & $\begin{array}{c}\text { Thickness, } \\
\text { to sarurated } \\
\text { zone, } \\
\text { ft }\end{array}$ & $\begin{array}{l}\text { Bulk } \\
\text { - density, } \\
\text { g/cm3 }\end{array}$ & $\begin{array}{c}\text { Porosity, } \\
\text { vol } \%\end{array}$ & $\begin{array}{c}\text { Field } \\
\text { capacity. } \\
\text { vol } \%\end{array}$ & $\begin{array}{c}\text { Sat. } \\
\text { hydraulic } \\
\text { conductivity. } \\
\text { cm/sec }\end{array}$ \\
\hline 4 & Arkansas Nuclear One & PWR & 15 & 10 & $\cdot 1.42$ & 46.3 & 27.5 & 2.0E-04 \\
\hline 4 & Wolf Creek & PWR & 10 & 35 & 1.48 & 44.2 & 17.5 & 7.2E-04 \\
\hline 4 & River Bend & BWR & 3 & 80 & 1.64 & 38 & 9 & $6.6 \mathrm{E} \cdot 03$ \\
\hline 4 & Waterford & PWR & 15 & 55 & 1.42 & 46.3 & 27.5 & $2.0 \mathrm{E} \cdot 04$ \\
\hline 4 & Callaway & PWR & 15 & 15 & 1.42 & 46.3 & 27.5 & $2.0 E-0-1$ \\
\hline 4 & Grand Gulf & BWR & 15 & 70 & 1.42 & 46.3 & 27.5 & $2.0 \mathrm{E} \cdot 0-4$ \\
\hline 4 & Cooper & BWR & 10 & 10 & 1.48 & 44.2 & 17.5 & 7.2E-0 \\
\hline 4 & Fort Calhoun & PWR & 10 & 2 & 1.48 & 44.2 & 17.5 & 7.2E.04 \\
\hline 4 & Comanche Peak & PWR & 10 & 40 & 1.48 & 44.2 & 17.5 & 7.2E-04 \\
\hline 4 & South Texas & PWR & 6 & 90 & 1.49 & 43.7 & 12 & $1.9 \mathrm{E}-03$ \\
\hline
\end{tabular}

Table B.2.1-5. Physical data for vadose zone in Region 5.

\begin{tabular}{|c|c|c|c|c|c|c|c|c|}
\hline \multirow[b]{2}{*}{ Region I } & \multirow[b]{2}{*}{ Site } & \multirow[b]{2}{*}{ Fuel type } & \multicolumn{6}{|c|}{ Vadose zone } \\
\hline & & & $\begin{array}{l}\text { Clay } \\
\text { content. } \\
\text { wt } \%\end{array}$ & $\begin{array}{c}\text { Thickness, } \\
\text { to saturated } \\
\text { zone, } \\
\text { ft }\end{array}$ & $\begin{array}{c}\text { Bulk } \\
\text { density, } \\
\text { g/cm3 }\end{array}$ & $\begin{array}{c}\text { Porosity, } \\
\text { vol } \%\end{array}$ & $\begin{array}{c}\text { Field } \\
\text { capacity, } \\
\text { vol } \%\end{array}$ & $\begin{array}{c}\text { Sat. } \\
\text { hydraulic } \\
\text { conductivity, } \\
\mathrm{cm} / \mathrm{sec}\end{array}$ \\
\hline 5 & Palo Verde & PWR & 6 & 15 & 1.49 & 43.7 & 12 & $1.9 \mathrm{E}-03$ \\
\hline 5 & Diablo Canyon & PWR & 10 & 10 & 1.50 & 40 & 10 & 6.5E-03 \\
\hline 5 & Humboldt Bay & BWR & 1 & 12 & 1.64 & 38 & 9 & $6.6 \mathrm{E}-03$ \\
\hline 5 & Rancho Seco & PWR & $!$ & 200 & 1.64 & 38 & 9 & $6.6 \mathrm{E}-03$ \\
\hline 5 & San Onofre & PWR & 0 & 50 & 1.50 & 40 & 10 & $6.5 E-03$ \\
\hline 5 & Trojan & PWR & 15 & 30 & 1.42 & 46.3 & 27.5 & $2.0 \mathrm{E}-0.4$ \\
\hline 5 & Washington . Vuclear & BWR & 1 & 230 & 1.64 & 38 & 9 & $6.6 \mathrm{E}-03$ \\
\hline 5 & Hanford & DOE SNF & 3 & 246 & 1.66 & 40 & 12 & $6.6 \mathrm{E}-03$ \\
\hline 5 & Hanford & DOE HLW & 3 & 246 & 1.66 & 40 & 12 & $6.6 \mathrm{E}-03$ \\
\hline 5 & Idaho National Engr Laboratory & DOE SNF & 3 & 62 & 1.50 & 48.7 & 14 & 7.0E-05 \\
\hline 5 & Fort Si Vrain & DOE SNF & 3 & 23 & 1.64 & 38 & 9 & $6.6 \mathrm{E}-03$ \\
\hline
\end{tabular}

\section{B.2 Water Flow Through the Saturated Zone}

The information in columns 4 through 11 of Tables B.2.2-1, B.2.2-2, B.2.2-3, B.2.2-4, and B.2.2-5 was obtained from Reference 11 and is presented here by region. The information in column 12 was added as is described in Section 2.2 of this report. Column 13 is the sum of the distance from the reactor to the point of groundwater emergence into surface streams and the 1,600 feet given in column 12. 
Table B.2:2-1. Physical data for satturated zone in Region 1.

\begin{tabular}{|c|c|c|c|c|c|c|c|c|c|c|c|c|}
\hline \multirow[b]{2}{*}{ Region } & \multirow[b]{2}{*}{ Silc } & \multirow[b]{2}{*}{ Fucl typ: } & \multicolumn{10}{|c|}{ Salturaled zeme } \\
\hline & & & $\begin{array}{c}\text { Clay } \\
\text { conleui, } \\
\text { wI \%, } \\
\end{array}$ & $\begin{array}{c}\text { Kol for P'u. } \\
\quad \text { milg }\end{array}$ & $\begin{array}{c}\text { Distance } \\
\text { to outl-fill, } \\
\text { fi }\end{array}$ & $\begin{array}{c}\text { Bulk } \\
\text { density, } \\
\text { g/culu3 }\end{array}$ & $\begin{array}{c}\text { Porosity. } \\
\text { vol \%, }\end{array}$ & $\begin{array}{c}\text { Reiaclor } \\
\text { GW iravel } \\
\text { distince. } \\
\text { yrs }\end{array}$ & $\begin{array}{l}\text { Reactor } \\
\text { GW iravel } \\
\text { timts, } \\
\text { yrs } \\
\end{array}$ & $\begin{array}{c}\text { Soil } \\
\text { classification } \\
C=\text { course } \\
P=\text { line } \\
\end{array}$ & $\begin{array}{c}\text { ISFSI } \\
\text { added } \\
\text { distance, } \\
f \mathrm{f}\end{array}$ & $\begin{array}{c}\text { ISI:SI } \\
\text { GW Ifavel } \\
\text { distiulce. } \\
\text { fi }\end{array}$ \\
\hline Regiun I & & & & & & & & & & & 10 ISFSI & \\
\hline 1 & IladdauI Neck & PWR & 1 & 10 & 50 & 1.64 & 38 & 492 & & $\mathbf{C}$ & $16(x)$ & $2(x) 2$ \\
\hline 1 & Millstone & PWR \& BWK & 3 & 10) & 311 & 1.64 & 38 & $|(x)|$ & 6 & $\mathbf{c}$ & 1600 & 2601 \\
\hline 1 & Sialem/llope Creck & PWK \& HWR & 1 & 10 & 60 & 1.64 & 38 & 62.3 & 2 & $\mathbf{p}$ & $16(x)$ & 2223 \\
\hline 1 & Pilgriin & IBWR & 1 & 10 & 55 & 1.64 & 38 & 492 & & $\mathbf{C}$ & $I(x)$ & $2(x) 2$ \\
\hline 1 & Stabrook & PWR & $\mathbf{I}$ & 10 & 25 & 1.64 & 38 & 361 & 0 & c & $\lg (x)$ & 1961 \\
\hline 1 & Maine Yankec & PWK & 1 & 111 & 7.5 & 1.64 & 38 & 2756 & 4 & $\mathbf{F}$ & 1600 & 4.3 .56 \\
\hline 1 & Calverl Cliffs & PWR & III & 100 & 50 & 1.48 & 44.2 & 492 & & $\mathbf{p}$ & $16(x)$ & $2(x) 2$ \\
\hline 1 & Oyster Creek & HWR & 3 & 11) & 17 & 1.64 & 38 & 984 & $\mathbf{1}$ & $\mathbf{C}$ & $\ln (x)$ & 2584 . \\
\hline 1 & Filzpatrick/Ninc Milc Point & BWR & $\mathbf{I}$ & 10 & 3.5 & 1.64 & 38 & 16.38 .5 & 6 & $\mathbf{F}$ & $16(x)$ & 32.38 .5 \\
\hline 1 & Ginna & PWR & 1 & 10 & 10 & 1.64 & 38 & 1542 & & $\mathbf{F}$ & 1600 & 3142 \\
\hline 1 & Indian Poinı & PWK \& BWR & 1 & 10 & 10 & 1.64 & 38 & 476 & 1 & $\mathbf{F}$ & $16(1)$ & 2076 \\
\hline 1 & Yanket-Kowe & PWR & 15 & $I(x)$ & 15 & 1.42 & 46.3 & 29.5 & & C & $16(x)$ & 1845 \\
\hline 1 & Heaver Valley & PWR & $\mathbf{I}$ & 10 & 41 & 1.64 & 38 & 449 & 12 & $\mathbf{F}$ & $16(x)$ & 2(24) \\
\hline 1 & Limerick & HWR & 0 & 0 & 100 & 1.65 & 5 & 787 & 3 & $\mathbf{F}$ & 1600 & 2387 \\
\hline 1 & Peach Bontom & HWR & 3 & 10 & 7 & 1.64 & 38 & 295 & & $\mathbf{F}$ & $16(x)$ & 189.5 \\
\hline 1 & Suscuuchimn: & BWR & n) & () & 50 & 1.65 & 5 & $4(x)$ & 9 & C & $16(x)$ & $2(x)$ \\
\hline 1 & Three Mile Island & PWR & 3 & 10 & 10 & 1.64 & 38 & 591 & o & C & $16(y)$ & $2|9|$ \\
\hline 1 & Vermum Yankece & HWK & 6 & 10 & 111 & 1.49 & 43.7 & 197 & & C & $16(x)$ & 1797 \\
\hline 1 & West Valley Dellos Projecl & IOOE HLW & 3 & 10 & 20) & 2.10 & 21.9 & $2(x \times)$ & 32 & C & 0 & $2(x)$ \\
\hline
\end{tabular}


Table 13.2.2-2. Physical data for saturilted zone in Region 2.

\begin{tabular}{|c|c|c|c|c|c|c|c|c|c|c|c|c|}
\hline \multirow[b]{2}{*}{ Reyion } & \multirow[b]{2}{*}{ Sile } & \multirow[b]{2}{*}{ Fucl typu } & \multicolumn{10}{|c|}{ Silluralled zone } \\
\hline & & & $\begin{array}{c}\text { Clay } \\
\text { content. } \\
\text { wI ' }\end{array}$ & $\begin{array}{c}\text { Ku for } P u \text {, } \\
m i l / g\end{array}$ & $\begin{array}{c}\text { I Distance } \\
\text { Wo cut - fall, } \\
\text { Fi }\end{array}$ & $\begin{array}{c}\text { Butk } \\
\text { densily, } \\
\text { g/cmin }\end{array}$ & $\begin{array}{c}\text { Porosity, } \\
\text { vol \% }\end{array}$ & $\begin{array}{c}\text { Reactor } \\
\text { GW travel } \\
\text { distance. } \\
\text { yrs } \\
\end{array}$ & $\begin{array}{l}\text { Reacior } \\
\text { GW travel } \\
\text { lime, } \\
\text { yrs }\end{array}$ & $\begin{array}{c}\text { Soil } \\
\text { classification } \\
C=\text { course } \\
F=\text { finc }\end{array}$ & $\begin{array}{c}\text { ISFSI } \\
\text { addued } \\
\text { dislanice, } \\
\text { fi }\end{array}$ & $\begin{array}{c}\text { ISISSI } \\
\text { GW Iravel } \\
\text { dislinte. } \\
\text { fi }\end{array}$ \\
\hline 2 & Browns Fetry & BWWR & 1 & 10 & 44 & 1.64 & 38 & 492 & & $\bar{F}$ & 1600 & $2(K) 2$ \\
\hline 2 & Farley & PWR & 0 & 10 & 80 & 1.6 .5 & 3.5 & 984 & 10 & $\mathbf{F}$ & $16(x)$ & 2.584 \\
\hline 2 & Crystal River & PWR & 0 & 10) & 80 & 1.65 & 35 & 29.5 & & $\mathbf{F}$ & $I(t)(x)$ & I895 \\
\hline 2 & St. Lucit: & PWR & 3 & 10 & 145 & 1.64 & 38 & 699 & 27 & $\mathbf{C}$ & $16(x)$ & 2294 \\
\hline 2 & Turkcy Point & PWK & 1 & 10 & 70 & 1.64 & 38 & 164 & & C & $16(x)$ & 1764 \\
\hline 2 & Ilalch & HWR & 1 & 10) & 3.5 & 1.64 & 38 & 984 & 30 & C & $16(x)$ & 2.584 \\
\hline 2 & Vogile & PWR & 6 & 10 & 50 & 1.49 & 4.3 .7 & 2789 & 1.5 & C & $16(x)$ & 4.780 \\
\hline 2 & Brunswick & PWR & 47 & 2.50 & 35 & 1.36 & 48.6 & 492 & 60 & C & $16(x)$ & 20092 \\
\hline 2 & Catawha & PWR & 10 & $I(x)$ & 55 & 1.48 & 44.2 & 689 & 1. & $\mathbf{F}$ & $\operatorname{lo}(x)$ & 2289 \\
\hline 2 & Ilarris & PWR \& BWR & 0 & 10 & 85 & 1.65 & 38 & 2395 & 7 & $\mathbf{F}$ & $16(x)$ & 39095 \\
\hline 2 & McGuire & PWR & 0 & 10 & 31) & 1.65 & 40 & 1960 & & $\mathbf{P}$ & $16(x)$ & $3.5(10)$ \\
\hline 2 & Oconce & PWR & 10 & $I(x)$ & 10) & 1.48 & 44.2 & 984 & & $\mathbf{F}$ & $16(N)$ & 2.584 \\
\hline 2 & Robinson & $P W R$ & 1 & 10 & 2.5 & 1.64 & 38 & 501 & & C & $16(0)$ & 2191 \\
\hline 2 & Summer & PWK & 0 & ) & 30) & 1.6 .5 & 5 & $3(x)$ & 7 & $\mathbf{F}$ & $16(0)$ & 4700 \\
\hline 2 & Sequivyah & $P W K$ & 15 & 1100 & 4.5 & 1.42 & 46.3 & $\operatorname{tox}(x)$ & 4 & F & $I f(x)$ & $2(10)$ \\
\hline 2 & Walts Har & PWR & 47 & 250 & 23 & 1.36 & 48.6 & 984 & 2 & $\mathbf{F}$ & $16(x)$ & 2.584 \\
\hline 2 & North Annil & PWR & 10 & $I(x)$ & 40 & 1.48 & 44.2 & 492 & & $\mathbf{F}$ & $16(x)$ & $2(x) 2$ \\
\hline 2 & Surry & PWR & 10 & $l(0)$ & .30 & 1.48 & 44.2 & $2(x) 1$ & & $\mathbf{F}$ & 1600 & 36016 \\
\hline 2 & Savamulh River Site & DOE-SNF & 6 & 10 & 50 & 2.00 & 40 & $2(x)$ & 8 & C & 0 & $20(x)$ \\
\hline 2 & Savannah River Sile & DOE-HILW & 6 & 10 & 50 & 2.00 & 40 & $32(x)$ & 1.3 & $\mathbf{C}$ & () & $32(x)$ \\
\hline
\end{tabular}


Table 13.2.2-3. Physical data for saturated zone in Region 3.

\begin{tabular}{|c|c|c|c|c|c|c|c|c|c|c|c|c|}
\hline \multirow[b]{2}{*}{ Rugion } & \multirow[b]{2}{*}{ Sile } & \multirow[b]{2}{*}{ Fucl lype } & \multicolumn{10}{|c|}{ Silluraled tone } \\
\hline & & & $\begin{array}{c}\text { Claly } \\
\text { conlinin, } \\
w 1 x_{1}\end{array}$ & $\begin{array}{c}\mathrm{Ku} \text { for Pu, } \\
\mathrm{mul} / \mathrm{g}\end{array}$ & $\begin{array}{c}\text { Dislance } \\
\text { lo out-fiall, } \\
\text { FI }\end{array}$ & $\begin{array}{c}\text { Bulk } \\
\text { dcusily. } \\
\text { g/cull3 }\end{array}$ & $\begin{array}{l}\text { Porusily, } \\
\text { vol \%\%, }\end{array}$ & $\begin{array}{c}\text { Reacilor } \\
\text { GW travel } \\
\text { distance, } \\
\text { yrs }\end{array}$ & $\begin{array}{l}\text { Reiciclor } \\
\text { GW Iravel } \\
\text { liules, } \\
\text { yrs } \\
\end{array}$ & $\begin{array}{c}\text { Suil } \\
\text { classificution } \\
C=\text { course } \\
f=\text { finc }\end{array}$ & $\begin{array}{c}\text { ISFSI } \\
\text { adilidd } \\
\text { distance, } \\
\text { fi }\end{array}$ & $\begin{array}{c}|S| F S \mid \\
\text { GW Iravel } \\
\text { distince. } \\
\text { Ii }\end{array}$ \\
\hline 3 & Duinc Armold & BWR & 3 & 10 & 20 & 1.64 & 38 & 1766 & & $F$ & $160(x)$ & 3366 \\
\hline 3 & Braidwobl & PWK & 3 & 10 & 14 & 1.64 & 38 & 21120 & 38.5 & C & $16(x)$ & 22720 \\
\hline 3 & Byron & PWR & 1.5 & 100 & 10 & 1.50 & 40 & 3609 & 25 & $\mathbf{F}$ & $16(x)$ & 52019 \\
\hline 3 & Clinton & HWK & 1 & 10) & 14 & 1.64 & 38 & $I(M x)$ & 1 & C & $16(x)$ & $26(x)$ \\
\hline 3 & Dresden/Murris & PWK \& BWR & 1 & 10 & 7 & 1.64 & 38 & $2(x) 1$ & & $\mathbf{p}$ & $16(x)$ & .9601 \\
\hline 3 & Lasialle County & HWR & 6 & (1) & 17 & 1.49 & 43.7 & 492 & & $\mathbf{P}$ & $\lg (x)$ & $2(x) 2$ \\
\hline 3 . & Quad Cilics & BWR & 1 & 10 & 30 & 1.64 & 38 & 591 & & $\mathbf{C}$ & 1600 & 2191 \\
\hline 3 & Zion & PWR & 3 & 10 & 20 & 1.64 & 38 & 3412 & & c & 1600 & 51112 \\
\hline 3 & Big Kock Point & BWR & 0 & 0 & 42 & 1.65 & 5 & 488 & & $\mathbf{F}$ & 1600 & 2088 \\
\hline 1 & Cuok & PWR & 3 & 10 & 20 & 1.64 & 38 & 492 & & C & $16(X)$ & $2(x) 2$. \\
\hline 3 & Eurico Fermi & HWR & () & 0) & 80 & 1.65 & 5 & 4.59 & 2 & $\mathbf{P}$ & $16(x)$ & $2(15)$ \\
\hline 3 & Palisades & PWR & 6 & 10 & 135 & 1.49 & 4.3 .7 & 295 & & $\mathbf{F}$ & $16(x)$ & 1895 \\
\hline 3 & Monticello & BWR & 3 & I0 & 30 & 1.64 & 38 & 492 & & $\mathbf{F}$ & $16(x)$ & $2(1) 2$ \\
\hline 3 & Prairic Islanal & PWK & 1 & 10 & $161)$ & 1.64 & 38 & 492 & & C & $\lg (x)$ & $2(x) 2$ \\
\hline 3 & Davis-Hesse & PWR & 0 & 0 & $I(x)$ & 1.65 & 5 & 2973 & & $\mathbf{F}$ & $I G(x)$ & 4.57 .1 \\
\hline 3 & Perry & BWR & 10 & 100 & 28 & 1.48 & 44.2 & $8(x)$ & 25 & $\mathbf{P}$ & $(6 x)$ & $24(x)$ \\
\hline 3 & Kewaunct & PWK & 3 & 10 & 60 & 1.64 & .38 & 492 & & $\mathbf{P}$ & $16(x)$ & $2(Y) 2$ \\
\hline 3 & I acrossce & HWR & 1 & 10) & I60 & 1.64 & 38 & 370 & & C est & $16(x)$ & 1971 \\
\hline 3 & Point Beach & PWR & 6 & 10 & 54 & 1.49 & 4.3 .7 & 1631 & & c & $16(x)$ & .32 .31 \\
\hline
\end{tabular}


Table 13.2.2-4. Pliysical data for salturated zone in Region 4.

\begin{tabular}{|c|c|c|c|c|c|c|c|c|c|c|c|c|}
\hline \multirow[b]{2}{*}{ Rcugion! } & \multirow[b]{2}{*}{ Silt: } & \multirow[b]{2}{*}{ Fucl tyjo: } & \multicolumn{10}{|c|}{ Sillumaled zence } \\
\hline & & & $\begin{array}{c}\text { Clay } \\
\text { cointent. } \\
\text { wI \%, }\end{array}$ & $\begin{array}{c}\text { Kal for } P_{u} \text {. } \\
m 1 / g\end{array}$ & $\begin{array}{c}\text { Distimce } \\
\text { fo oul-fill, } \\
\text { Ii }\end{array}$ & $\begin{array}{c}\text { Mulk } \\
\text { densily. } \\
\text { g/cum? }\end{array}$ & $\begin{array}{l}\text { Porosity, } \\
\text { vol \% }\end{array}$ & $\begin{array}{c}\text { Reiaclor } \\
\text { GW Inavel } \\
\text { dislance, } \\
\text { yrs }\end{array}$ & $\begin{array}{l}\text { Reitclur } \\
\text { GW iravel } \\
\text { litic: } \\
\text { yrs }\end{array}$ & $\begin{array}{c}\text { Soil } \\
\text { classificaulion } \\
C^{\prime}=\text { course } \\
\Gamma=\text { finc }\end{array}$ & $\begin{array}{c}\text { ISFSI } \\
\text { anliled } \\
\text { dislance. } \\
\text { ff }\end{array}$ & $\begin{array}{c}\text { ISFSI } \\
\text { GW Iravel } \\
\text { disliance, } \\
\text { li }\end{array}$ \\
\hline 4 & Alkinnsass Nucleall (Once & PWIR & 15 & $\operatorname{lox})$ & 20 & 1.42 & 46.3 & 492 & 22.5 & $\mathbf{F}$ & $16(x)$ & $2(x) 2$ \\
\hline 4 & Wolf Creck & PWR & 10 & $1(x)$ & 35 & 1.48 & 44.2 & $25 \% 2$ & 356 & c & $16(x)$ & 4192 \\
\hline 4 & River Bsemal & HWR & 1 & 10 & 80 & 1.64 & 38 & $1(x \times 1) 7$ & 8 & $\mathbf{F}$ & $\operatorname{lf}(x)$ & 11607 \\
\hline 4 & Walcrford & PWR & 3 & 10 & 5.5 & 1.64 & 38 & NA & NA & $\mathbf{F}$ & $16(x)$ & NA \\
\hline 4 & Callaway & PWR & $\mathbf{I}$ & 10 & 20 & 1.64 & 38 & 2494 & 69 & $\mathbf{F}$ & 1600 & $4(k) 4$ \\
\hline 4 & Grand Gulf & BWK & $\mathbf{I}$ & 10 & 50 & 1.64 & 38 & 7317 & 1.3 & F est & $\ln (x)$ & 8917 \\
\hline 4. & Cooper & BWR & 1 & 10 & 56 & 1.64 & 38 & 197 & & $\dot{\mathbf{F}}$ & $16(x)$ & 1797 \\
\hline 4 & Fort Callowun & PWR & 1 & 10 & 60 & 1.64 & 38 & 492 & & $\mathbf{F}$ & $16(x)$ & $2(x) 2$ \\
\hline 4 & Conilanchc l'wak & PWR & 0) & 10 & 1.50 & I.6.5 & 5 & NA & NA & $\mathbf{F}$ & $16(x)$ & NA \\
\hline 4 & Soull Texas & PWK & 3 & 10 & 90 & 1.64 & 38 & 1601177 & 6.3 & C & $16(x)$ & 17677 \\
\hline
\end{tabular}

'Table 13.2.2-5. Physical data for saturated zone in Region 5.

\begin{tabular}{|c|c|c|c|c|c|c|c|c|c|c|c|c|}
\hline \multirow[b]{2}{*}{ Rcugion } & \multirow[b]{2}{*}{ Sile } & \multirow[b]{2}{*}{ Fucl lype } & \multicolumn{10}{|c|}{ Saluraled zone } \\
\hline & & & $\begin{array}{c}\text { Clay } \\
\text { content, } \\
w 1 \% \\
\end{array}$ & $\begin{array}{c}\text { Kal for Pu, } \\
\mathrm{IIII/g}\end{array}$ & $\begin{array}{c}\text { Distance } \\
\text { Ho cut-(iall, } \\
\text { |it }\end{array}$ & $\begin{array}{c}\text { Bulk } \\
\text { densily, } \\
\text { p/cun? }\end{array}$ & $\begin{array}{c}\text { Porusily. } \\
\text { vol \% }\end{array}$ & $\begin{array}{c}\text { Reactor } \\
\text { GW Iravel } \\
\text { distamce. } \\
\text { yrs }\end{array}$ & $\begin{array}{c}\text { Reacior } \\
\text { GW travel } \\
\text { limus. } \\
\text { yrs }\end{array}$ & $\begin{array}{c}\text { Soil } \\
\text { classificulion } \\
C=\text { course } \\
F=\text { finc }\end{array}$ & $\begin{array}{c}\text { ISFSI } \\
\text { adiled } \\
\text { dislance, } \\
\text { Ii }\end{array}$ & $\begin{array}{c}\text { ISISSI } \\
\text { GW Iravel } \\
\text { dislansec. } \\
\text { fi }\end{array}$ \\
\hline 5 & Pailo Verile & PWR & 6 & 10) & 15 & 1.49 & 43.7 & NA & NA & $\mathbf{C}$ & $16(x)$ & $\mathrm{NA}$ \\
\hline 5 & Diablo Canyoun & P'WR & 0 & 10 & 5 & 1.65 & 5 & 492 & & C & $16(0)$ & $2(N) 2$ \\
\hline 5 & Ilumboldll Bay & BWR & 1 & 10 & 50 & 1.64 & 38 & 550 & & c & $J 6(x)$ & 21.50 \\
\hline 5 & Ranchos Seco) & P'WI & 1 & 10 & $2(x)$ & 1.64 & 38 & NA & & $\mathbf{F}$ & 1600 & NA \\
\hline 5 & San Omulic & PWR & 0 & I1) & 8.50 & 1.65 & 5 & 492 & 1 & C & 16000 & $2(x) 2$ \\
\hline 5 & Troji:n & PWR & 10 & $1(x)$ & 30 & 1.48 & 44.2 & 295 & & $\mathbf{P}$ & $|6(x)|$ & 18015 \\
\hline 5 & Washinglon Nuclcar & IIWK & 1 & 10 & 230 & 1.64 & .38 & $|6(1)| \mid$ & 6 & C & $\ln (x)$ & $|761|$ \\
\hline 5 & Hanford & DOE SNF & 1 & 10 & 30 & 1.64 & 38 & $37(x)$ & 20 & c & 0) & $37(x)$ \\
\hline 5 & Hamlued & DOE HILW & 1 & (1) & 30 & 1.64 & 38 & $37(x)$ & 20 & C & 0 & $37(x)$ \\
\hline 5 & $\begin{array}{l}\text { Idtaloo Nialiontal Engr } \\
\text { I aiboral(uly }\end{array}$ & DOL: SNF & () & 10 & 250 & 1.90 & 23 & $31700(x)$ & 174 & BR & (1) & $317(x)$ \\
\hline 5 & Forl Si Vriill & DOE SNF & 1 & 10 & 25 & 1.64 & 38 & $45(x)$ & 29 & C & $16(x)$ & $61(x)$ \\
\hline
\end{tabular}




\section{Appendix C \\ Site Data Used \\ To Determine Surface Water Transport and Populations Using Surface Waters for Drinking}

Tables C.3.1-1, C.3.1-2. C.3-1.3, C.3.1-4, and C.3.1-5 provide a summation of the number of people drinking water from rivers that might transport contamination from degradation of SNF or HLW stored at those sites. This data was developed in Reference 13.

Table C.3.1-1. Drinking water population (affected by degrading storage) in Region 1.

\begin{tabular}{|c|c|c|c|c|c|}
\hline \multirow[b]{2}{*}{ Region } & \multirow[b]{2}{*}{ Site } & \multirow[b]{2}{*}{ State } & \multicolumn{3}{|c|}{ Population exposed } \\
\hline & & & Population & $\begin{array}{l}\text { Sum } \\
\text { pop/flow } \\
\text { pop/cfs }\end{array}$ & $\begin{array}{c}\text { River } \\
\text { Mouth } \\
\text { flow (cfs) }\end{array}$ \\
\hline 1 & Haddam Neck & CT & $0.00 E+00$ & 0.00 & \\
\hline 1 & Millstone & $\mathrm{CT}$ & $0.00 E+00$ & 0.00 & \\
\hline 1 & Salem/Hope Creek & $\mathrm{DE}$ & $0.00 E+00$ & 0.00 & \\
\hline 1 & Pilgrim & MA & $0.00 \mathrm{E}+00$ & 0.00 & \\
\hline 1 & Seabrook & MA & $0.00 \mathrm{E}+00$ & 0.00 & \\
\hline 1 & Maine Yankee & ME & $0.00 \mathrm{E}+00$ & 0.00 & \\
\hline 1 & Calvert Cliffs & $\mathrm{MD}$ & $0.00 \mathrm{E}+00$ & 0.00 & \\
\hline 1 & Oyster Creek & NJ & $0.00 \mathrm{E}+00$ & 0.00 & \\
\hline 1 & Fitzpatrick/Nine Mile Point & NY & $6.90 \mathrm{E}+04$ & 3.13 & 22020 \\
\hline 1 & Ginna & NY & $6.27 E+05$ & 28.47 & 22020 \\
\hline 1 & Indian Point & NY & $0.00 E+00$ & 0.00 & \\
\hline 1 & Yankee-Rowe & NY & $0.00 E+00$ & 0.00 & \\
\hline 1 & Beaver Valley & PA & $6.10 E+06$ & 40.62 & 494000 \\
\hline 1 & Limerick & $\mathrm{PA}$ & $2.83 E+06$ & 1205.45 & 2700 \\
\hline 1 & Peach Bottom & PA & $1.73 E+06$ & 44.24 & 39200 \\
\hline$!$ & Susquehanna & PA & $2.00 E+06$ & 52.05 & 39200 \\
\hline 1 & Three Mile Island & P.A & $1.87 E+06$ & 48.05 & 39200 \\
\hline 1 & Vermont Yankee & $\mathrm{VT}$ & $0.00 \mathrm{E}+00$ & 0.00 & \\
\hline 1 & West Valley Demo Project & NY & $1.30 \mathrm{E}+06$ & 6.46 & 190000 \\
\hline
\end{tabular}


Table C.3.1-2. Drinking water population (affected by degrading storage) in Region 2.

\begin{tabular}{|c|c|c|c|c|c|}
\hline \multirow[b]{2}{*}{ Region } & \multirow[b]{2}{*}{ Site } & \multirow[b]{2}{*}{ State } & \multicolumn{3}{|c|}{ Population $\epsilon$ xposed } \\
\hline & & & Population & $\begin{array}{c}\text { Sum } \\
\text { pop/flow } \\
\text { pop/cfs }\end{array}$ & $\begin{array}{c}\text { River } \\
\text { Mouth } \\
\text { flow (cfs) } \\
\end{array}$ \\
\hline 2 & Browns Ferty & AL & $2.69 E+06$ & 12.39 & 494000 \\
\hline 2 & Farley & AL & $0.00 E+00$ & 0.00 & \\
\hline 2 & Crystal River & FL & $0.00 E+00$ & 0.00 & \\
\hline 2 & St. Lucie & FL & $0.00 \mathrm{E}+00$ & 0.00 & \\
\hline 2 & Turkey Point & FL & $0.00 E+00$ & 0.00 & \\
\hline 2 & Hatch & GA & $0.00 E+\infty$ & 0.00 & \\
\hline 2 & Vogtle & GA & $6.28 \mathrm{E}+04$ & 6.06 & 12000 \\
\hline 2 & Brunswick & NC & $0.00 \mathrm{E}+00$ & 0.00 & \\
\hline 2 & Catawba & NC & $2.54 E+05$ & 41.36 & 14689 \\
\hline 2 & Harris & $\mathrm{NC}$ & $5.19 E+05$ & 105.21 & 5609 \\
\hline 2 & McGuire & $\mathrm{NC}$ & $7.22 E+05$ & 151.51 & 14689 \\
\hline 2 & Oconee & SC & $5.35 E+05$ & 130.52 & 12000 \\
\hline 2 & Robinson & SC & $1.80 \mathrm{E}+03$ & 0.18 & 10014 \\
\hline 2 & Summer & SC & $3.43 E+05$ & 47.12 & 14689 \\
\hline 2 & Sequoyah & TN & $3.52 E+06$ & 32.58 & 494000 \\
\hline 2 & Watts Bar & TN & $3.53 \mathrm{E}+06$ & 33.11 & 494000 \\
\hline 2 & North Anna & VA & $1.50 \mathrm{E}+03$ & 3.75 & 400 \\
\hline 2 & Surry & VA & $0.00 \mathrm{E}+00$ & 0.00 & \\
\hline 2 & Savannah River Site & SC & $6.28 \mathrm{E}+04$ & 6.06 & 12000 \\
\hline 2 & Savannah River Site & SC & $6.28 E+04$ & 6.06 & 12000 \\
\hline
\end{tabular}

Table C.3.1-3. Drinking water population (affected by degrading storage) in Region 3.

\begin{tabular}{|c|c|c|c|c|c|}
\hline \multirow[b]{2}{*}{ Region } & \multirow[b]{2}{*}{ Site } & \multirow[b]{2}{*}{ State } & \multicolumn{3}{|c|}{ Population exposed } \\
\hline & & & Population & $\begin{array}{c}\text { Sum } \\
\text { pop/flow } \\
\text { pop/cfs }\end{array}$ & $\begin{array}{c}\text { River } \\
\text { Mouth } \\
\text { flow (cfs) }\end{array}$ \\
\hline 3 & Duane Arnold & IA & $3.09 E+06$ & 9.96 & 494000 \\
\hline 3 & Braidwood & IL & $2.70 E+05$ & 16.91 & 494000 \\
\hline 3 & Byron & IL & $3.09 E+06$ & 9.96 & 494000 \\
\hline 3 & Clinton & II & $2.96 \mathrm{E}+06$ & 8.17 & 494000 \\
\hline 3 & Dresden/Morris & II & $3.10 E+06$ & 16.90 & 494000 \\
\hline 3 & Lasalle County & II & $3.10 E+06$ & 16.91 & 494000 \\
\hline 3 & Quad Cities & IL & $3.33 E+06$ & 14.59 & 494000 \\
\hline 3 & Zion & IL & $7.96 \mathrm{E}+06$ & 44.99 & 177011 \\
\hline 3 & Big Rock Point & MI & $5.42 E+03$ & 0.03 & 177011 \\
\hline 3 & Cook & MI & $5.32 E+05$ & 3.00 & 177011 \\
\hline 3 & Enrico Fermi & MI & $5.42 E \div 05$ & 2.77 & 196032 \\
\hline 3 & Palisades & MI & $2.08 E+05$ & 1.18 & 177011 \\
\hline 3 & Monticello & $\mathrm{MN}$ & $3.33 E+06$ & 14.59 & 494000 \\
\hline 3 & Prairie Island & MN & $3.33 E+06$ & 14.59 & 494000 \\
\hline 3 & Davis-Besse & $\mathrm{OH}$ & $7.34 E+05$ & 3.74 & 196032 \\
\hline 3 & Perry & $\mathrm{OH}$ & $1.93 E+06$ & 9.86 & 196032 \\
\hline 3 & Kewaunee & WI & $2.01 E+05$ & 1.13 & 177011 \\
\hline 3 & Lacrosse & WI & $3.33 E+06$ & 14.59 & 19.1000 \\
\hline 3 & Point Beach & WI & $2.01 E+05$ & 1.12 & 177011 \\
\hline
\end{tabular}


Table C.3.1-4. Drinking water population (affected by degrading storage) in Region 4.

\begin{tabular}{|c|c|c|c|c|c|}
\hline \multirow[b]{2}{*}{ Region } & \multirow[b]{2}{*}{ Site } & \multirow[b]{2}{*}{ State } & \multicolumn{3}{|c|}{ Population exposed } \\
\hline & & & Population & $\begin{array}{c}\text { Sum } \\
\text { pop/flow } \\
\text { pop/cfs }\end{array}$ & $\begin{array}{c}\text { River } \\
\text { Mouth } \\
\text { flow (cfs) } \\
\end{array}$ \\
\hline 4 & Arkansas Nuclear One & $\overline{A R}$ & $2.36 \mathrm{E}+06$ & 4.78 & 494000 \\
\hline 4 & Wolf Creek & $\mathrm{KS}$ & $2.44 E+06$ & 22.31 & 494000 \\
\hline 4 & River Bend & LA & $2.36 E+06$ & 4.78 & 494000 \\
\hline 4 & Waterford & LA & $2.31 E+06$ & 0.08 & 494000 \\
\hline 4 & Callaway & MO & $4.25 E+06$ & 23.92 & 494000 \\
\hline 4 & Grand Gulf & MS & $2.36 \mathrm{E}+06$ & 4.78 & 494000 \\
\hline 4 & Cooper & NE & $5.01 E+06$ & 36.76 & 494000 \\
\hline 4 & Fort Calhoun & NE & $5.27 E+06$ & 44.13 & 494000 \\
\hline 4 & Comanche Peak & TX & $2.55 E+05$ & 17.41 & 8387 \\
\hline 4 & South Texas & TX & $0.00 \mathrm{E}+00$ & & \\
\hline
\end{tabular}

Table C.3.1-5. Drinking water population (affected by degrading storage) in Region 5 .

\begin{tabular}{|c|c|c|c|c|c|}
\hline \multirow[b]{2}{*}{ Region } & \multirow[b]{2}{*}{ Site } & \multirow[b]{2}{*}{ State } & \multicolumn{3}{|c|}{ Population exposed } \\
\hline & & & Population & $\begin{array}{l}\text { Sum } \\
\text { pop/flow } \\
\text { pop/cfs }\end{array}$ & $\begin{array}{c}\text { River } \\
\text { Mouth } \\
\text { flow (cfs) }\end{array}$ \\
\hline 5 & Palo Verde & $A Z$ & $0.00 \mathrm{E}+00$ & 0.00 & \\
\hline 5 & Diablo Canyon & $\mathrm{CA}$ & $0.00 E+00$ & 0.00 & \\
\hline 5 & Humboldt Bay & $\mathrm{CA}$ & $0.00 E+00$ & 0.00 & \\
\hline 5 & Rancho Seco & $\mathrm{CA}$ & $0.00 E+\infty 0$ & 0.00 & \\
\hline 5 & San Onofre & $\mathrm{CA}$ & $0.00 E+00$ & 0.00 & \\
\hline 5 & Trojan & OR & $3.71 E+04$ & 0.16 & 230000 \\
\hline 5 & Washington Nuclear & WA & $1.64 E+05$ & 1.04 & 230000 \\
\hline 5 & Hanford & WA & $1.64 E+05$ & 1.04 & 230000 \\
\hline 5 & Hanford & WA & $1.64 E+05$ & 1.04 & 230000 \\
\hline 5 & $\begin{array}{l}\text { Idaho National Engr } \\
\text { Laboratory }\end{array}$ & ID & $1.56 \mathrm{E}+05$ & 2.30 & 230000 \\
\hline 5 & Fort St Vrain & $\mathrm{CO}$ & $5.01 E+06$ & 36.93 & 494000 \\
\hline
\end{tabular}

